\title{
Illuminating Roman Vishniac: A Career in Biological Photography and Cinematography
}

\author{
Howard J. Radzyner and Norman J. Barker
}

Despite the fame of Roman Vishniac's photography of Jewish communities in pre-Holocaust Europe; what is relatively unknown today to the photography or science communities despite the recognition it received at the time of its creationis that Vishniac's major efforts in photography were neither documentary nor artistic. Rather, the vast majority of his lifetime of photographic work focused on the biological world. Reviewed here is the phenomenal scope and quantity of biological photography and cinematography produced by Roman Vishniac over a five-decade period. From zoo animals to the tiniest of microorganisms, from time-lapse studies of vascular physiology to widely distributed biology classroom films, from spreads in LIFE magazine to advertisements for an insect sting analgesic; Vishniac's ability to capture and create images - almost exclusively of living subjects - was sought after by scientific researchers, popular magazines, movie producers, news organizations and commercial entities. Vishniac's body of scientific photography, both still and ciné, often produced by him from initial concept through writing and shooting - in an age before the technological advances in imaging that we all now enjoy - and despite its later eclipse by his own earlier images, was regarded as the finest and most imaginative of its time.

\section{OPEN ACCESS}

\section{Keywords}

Vishniac, photomicrography, cinematography, scientific photography, biological photography

\section{Introduction}

Roman Vishniac and his family, Jewish refugees fleeing Nazi Germany, arrived in New York City (NYC) on 31 December 1940. By 8 September 1941 — a scant eight months later — The New York Times (NYT) reported that he had won an award from the New York Zoological Society (more commonly known as The Bronx Zoo) for an entry in their annual photography competition. (NYT 1941) In his two-page, singlespaced, letter of thanks to the Society, dated 18 October 1941, Vishniac stated a philosophy of photography to which he zealously adhered over a five-decade career: "I tried to picture the animals in the Zoo as personalities. Not an animal did I want to show but the animal with his particular qualities and expressions.". (Vishniac's underscores in the original "carbon copy" on foolscap.) (Vishniac 1941) This anthropomorphic approach and philosophy, almost unique in its time, permeated Vishniac's work in biological photography and cinematography leading him to become the pre-eminent photographer of the life sciences from the 1950s through the 1970 s, continuing to work until just a few years before his death in 1990. While some of the details of Vishniac's early life and career have been lost to the fog of revolution, wars, forced migrations and time, the body of work in biological photography and cinematography that he created and the widespread dissemination that it received were unparalleled in their time. (Figure 1)

Vishniac's documentary images (primarily in still media but with some surviving motion picture footage) of pre-Holocaust life among the Jewish population of Eastern Europe are widely known and published and have been widely honored in the art and photography worlds. This documentary aspect of Vishniac's work has been the subject of numerous exhibitions in the United States (US) and internationally, books, and other publications. (Benton 2015A) Of note, recent research has cast

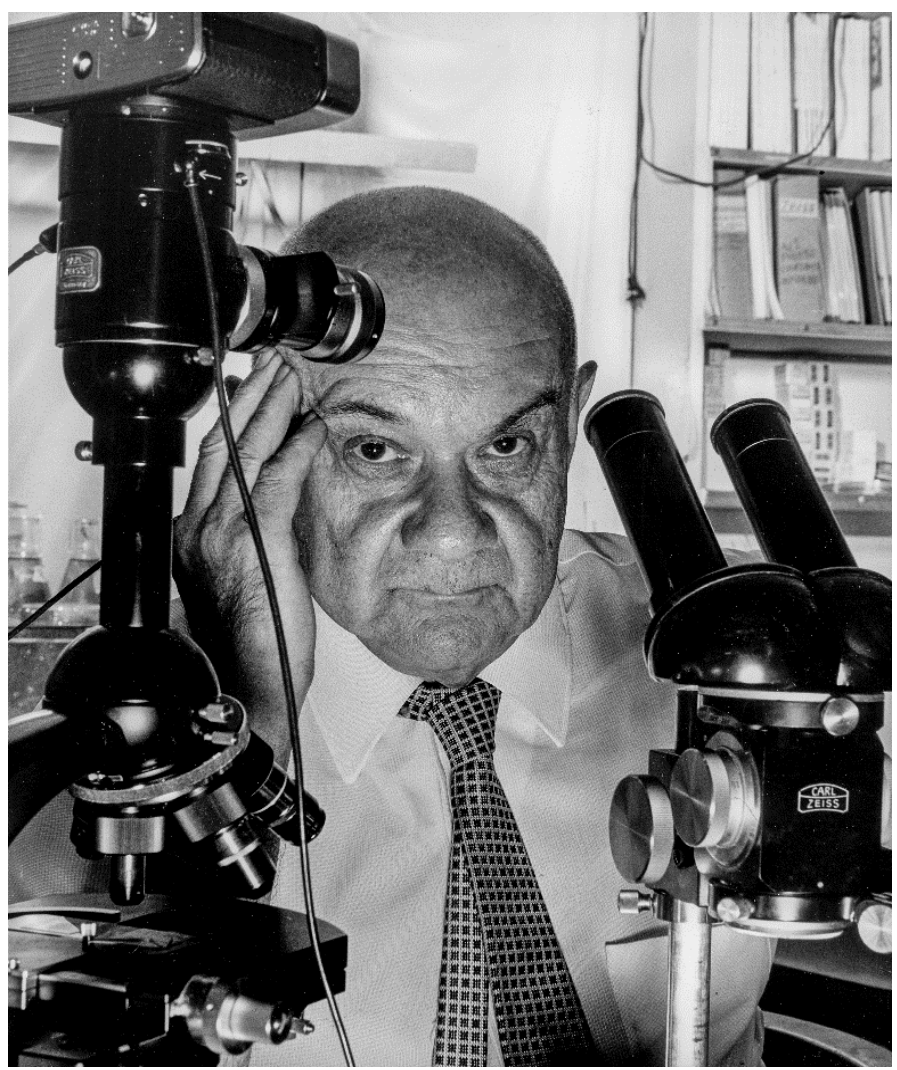

Figure 1. Roman Vishniac in his laboratory with his Zeiss microscopes, 1967. (C) Philippe Halsman / Magnum Photos

doubt on the veracity of some of Vishniac's descriptions and captioning of this work, as well his description of the motivating factor(s) in their creation. (Newhouse 2010) Similarly, verifiable sources regarding Vishniac's early years and education, academic achievement or position and 
professional qualifications are unavailable. Little discussion or review of Vishniac's biological photography has been presented or published since the 1950s.

Vishniac's most important documentary photography, which was produced over the relatively brief period circa $1935-1938$, was brought to prominence first in the late 1960s through the efforts of Cornell Capa and the International Fund for Concerned Photography; and then by its successor institution the International Center for Photography (ICP) where the Roman Vishniac Archive (RVA-ICP) was established in 2007. It is paradoxical that this earlier work has largely eclipsed Vishniac's later, seminal and previously widely appreciated and acclaimed work in biological photography and cinematography. His work in biological photography was a life-long effort of exceptional quantity, breadth and depth that occupied him professionally — with great success, recognition and honor — for a period of over 50 years. In this paper we seek redress this imbalance and to consider why and how this occurred.

\section{Russia, Germany and France (1897 - 1940)}

Born in 1897 near St. Petersburg, Russia, Roman Vishniac was the scion of a wealthy family. He grew up living in Moscow under Tsarist rule in one of the few Jewish families permitted to live outside of the "Pale of Settlement". As a child he was initially educated privately in the family home by tutors (as was the custom at the time) and he developed a keen interest in both biology and photography at a young age. Vishniac claimed, as noted in various sources, to have made his first scientific photograph at age seven when he placed his box camera to the eyepiece of his microscope to photograph a magnified view of a cockroach leg. (Kinkead 1955B pg. 31, Sabin 1978, Mitgang 1983)

After secondary education at a private academy, Vishniac entered Moscow University in 1914. Although reliable details regarding this period are scant, he seems to have performed research in the laboratory of Nikolay Koltzloff; a leading developmental biologist based at the Shanyavsky Institute (now the Russian State University for the Humanities) who made the induced metamorphosis of Ambystoma mexicanum's from aquatic newt to terrestrial salamander a preferred animal model for the study of the physiology of animal transformation and maturation. (Soyfer 2001) However, the results of the research that Vishniac is said to have conducted were never published due to the unstable socio-political situation that evolved in Moscow as a result of Russia's entry in to World War I in November 1914; followed by the Russian Revolution which commenced in February 1917; and which continued in various forms until the establishment of the Union of Soviet Socialist Republics in 1922. (Kinkead 1955B pgs. 32-33)

While initially unscathed by the revolutionary upheaval, by 1918 Vishniac's parents felt compelled to leave Russia and they relocated to Berlin, Germany. Roman remained in Moscow, probably to complete his studies. In 1920 he immigrated to Berlin via Latvia where he and Luta Bagg were married. As a result of marriage to a Latvian citizen Vishniac was able to obtain Latvian citizenship and a Latvian passport which subsequently provided him, his wife and their two children (who were also granted Latvian citizenship) with some degree of protection during the rise of Nazism in Germany.

In Berlin, Vishniac continued his interest in photography influenced by the modernist vein that was fashionable at the time. He also continued working in both biology and biological photography and lectured at various camera clubs and scientific groups where he was a member. (Eskildsen 2015) Deriving from the "street photography" that he was practicing, Vishniac developed a small practice in photojournalism. A photograph by Vishniac of a book-burning at the Reichstag (the German parliament building) was syndicated and appeared in the US in Friday magazine. (Kinkead 1955B pg. 40) There is indication that during his Berlin years he produced work in biological photography in collaboration with individuals at the University of Pennsylvania. (Holt 1940) (Figure 2)

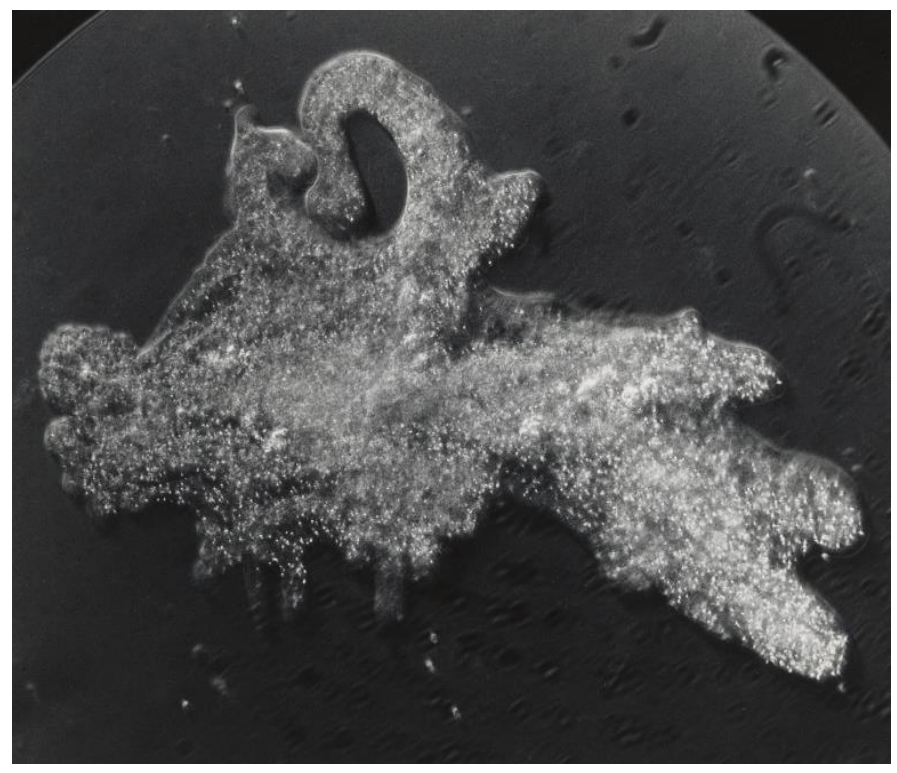

Figure 2. Amoeba proteus Catching a Protozoa, Ciliate paramecium, ca. 1928. One of the few existing Vishniac pre-WWII biological photographs. (C) Mara Vishniac Kohn, Courtesy International Center of Photography

Beginning in 1935 and continuing through 1938, Vishniac was commissioned and paid to produce documentary photography by the American Jewish Joint Distribution Committee (JDC) a US-based non-governmental organization - whose activities concentrated on supporting impoverished Jewish populations; and later on facilitating emigration from wartime Europe. To fulfill this commission, Vishniac made numerous trips to photograph Jewish populations over a great geographic expanse including countryside in Poland, Romania, Hungary, Carpathian Ruthenia (now the Ukraine), the Baltic States and Czechoslovakia; as well as the Polish cities of Warsaw, Krakow and Lodz. The image of Jews presented by Vishniac was not representative of the range of the economically and religiously diverse Jewish population in these areas - and in truth it was not meant to be. This was an assignment designed and undertaken to yield images that would support the JDC's fundraising efforts. Images from this project were first displayed in the US at the JDC headquarters in NY in 1938. (Benton 2015B pg. 118) The 2,000-odd photographic negatives and small 
amount of cinematographic material that survived through World War II and that eventually made their way to New York, were described by Edward Steichen, first Director of Photography at New York's Museum of Modern Art (MoMA) as “ '... among photography's finest documents of a time and place.'". (Kinkead 1955B pg. 38) (Figure 3)

With the rise of Nazism in Germany, the situation in Berlin became more dangerous for its Jewish residents. Vishniac's parents, who had travelled between Germany and the south of France for several years remained in France with their daughter and her family. After the Kristallnacht pogrom of November 1938, Vishniac's son, Wolf, and his daughter, Mara, were sent first to Riga, Latvia to the home of their maternal grandparents and then to Sweden. Vishniac based himself in both France and Germany during this period. While in France Vishniac continued his work in both documentary and scientific photography; including making additional photography trips from France to Poland and Germany. (Benton 2015B pg. 119)

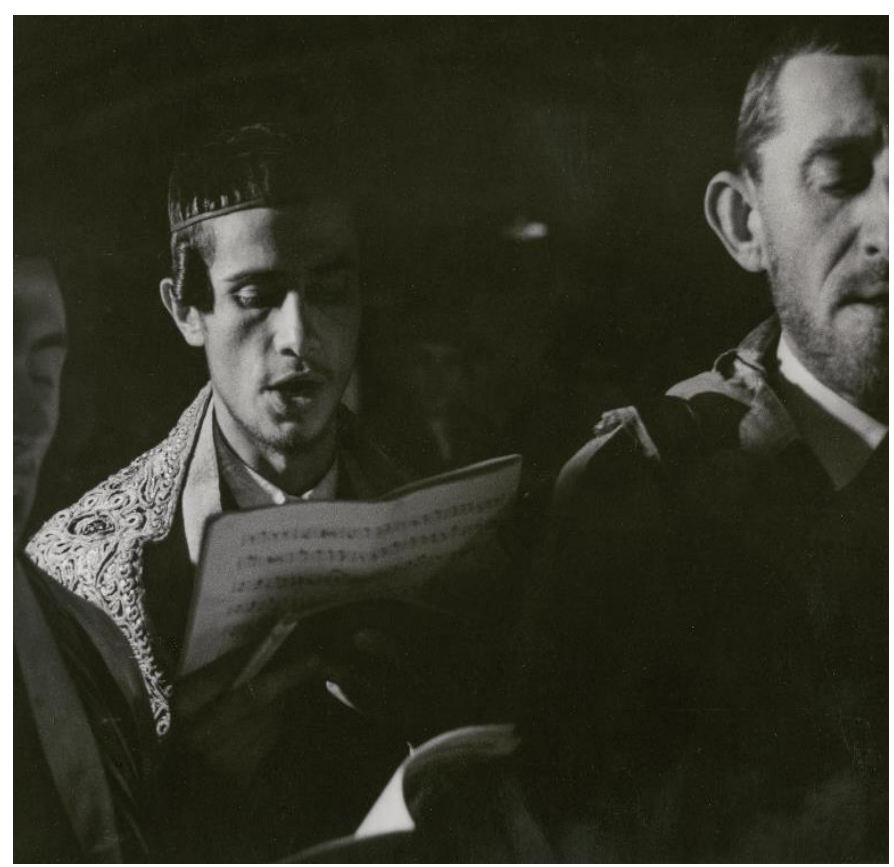

Figure 3. Meshorerim (choir singers) at the house of Rabbi Baruch Rabinowitz. Mukacevo, Czechoslovakia, ca.1937-1938. (C) Mara Vishniac Kohn, Courtesy International Center of Photography

In March 1940, while in France, Vishniac received what may have been his first - or at least what is the earliest documented - professional assignment for photography in the life sciences. The Division of Economic Entomology of Australia's Council for Scientific and Industrial Research's office in Paris commissioned Vishniac to provide images of beetles of the genera Agrilus and Chrysolina. (Wilson 1940) Whether this assignment was completed or deferred by the Vishniac family's next journey - to the United States (US) via Lisbon, Portugal is not known.

\section{United States (1941 - 1959)}

Immediately after his arrival in NYC on 31 December 1940 Vishniac began working as a freelance photographer. His work in his first NYC years consisted largely of portraiture and documentary photography for fundraising activities commissioned by social welfare and educational organizations. Much of this photography took place in the Jewish immigrant community where his work in this area was already known; and where his limited ability in English (despite speaking several European languages) was less of a handicap. Also most interestingly, and only recently discovered by researchers at RVA-ICP, he undertook similar documentary work depicting efforts to help with the settlement and integration in to the US of recent Chinese immigrants by organizations in NYC's Chinese-American community. (Ma \& Tam 2015) His most famous portraiture done during this period was a self-assigned, "spec" project which yielded an insightful series of images of Albert Einstein at work in Princeton, NJ. In 1978, Vishniac (who continued to make his living as a working photographer) issued and marketed a 7-print, limited edition portfolio of images from this project. (Figure 4)

During these early years in NYC Vishniac was also able to continue working in biological photography. His first sale of a scientific images, in 1942, was a series of photographs documenting the nuptial dance of the Mayfly to Nature Magazine. (Kinkead 1955B pg. 41) By 1943, Vishniac was sufficiently knowledgeable of the mechanisms in the US for the funding of artistic endeavors that he submitted a fellowship and funding application to the John Simon Guggenheim Memorial

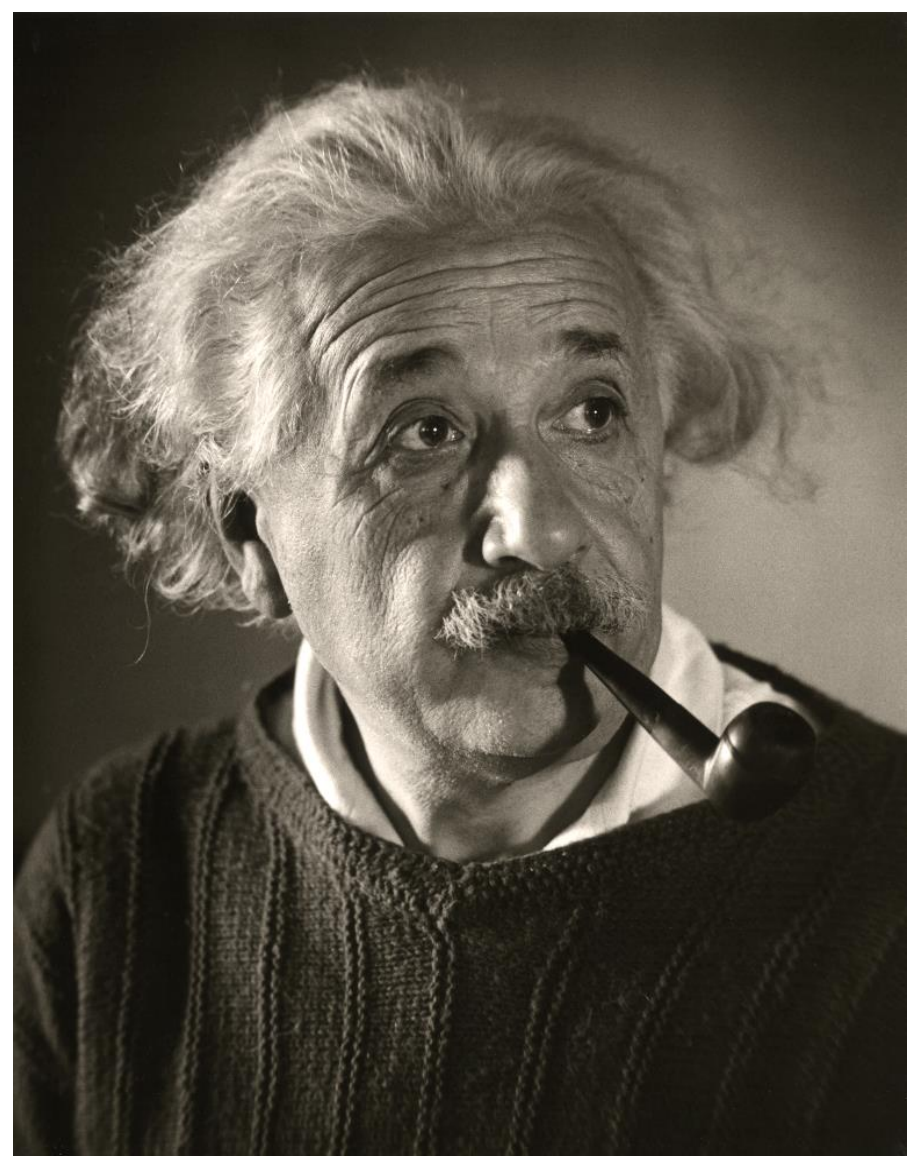

Figure 4. Albert Einstein, in his office. Princeton, New Jersey, 1941. (C) Mara Vishniac Kohn, courtesy International Center of Photography 


\section{ANIMAL PHOTOGRAPHY EXHIBIT IN OCTOBER}

66 NIMALS IN ACTION," a photoA graphic exhibit unusual because the photographer has made technique secondary to authenticity in representation of nature, will be placed on display in Stanley Field Hall on October 1. The special exhibit will continue through October 31 . The pictures, numbering 48 , are the work of Dr. Roman Vishniac, a zoologist who has specialized in "hunting by camera."

Dr. Vishniac's photographs are candid snapshots of animals, for the most part of difficult subjects such as small insects rather than large and spectacular birds and mammals. The creatures are neither dead speci-

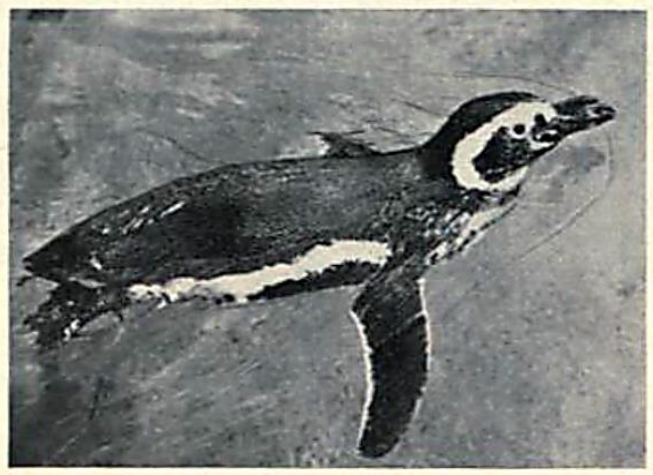

PENGUIN SWIMMING

One of Dr. Roman Vishniac's photographs of "Animals in Action," on exhibition in October.

mens arranged by the photographer nor live ones induced to pose; they are animals pursuing their normal routines of living. Dr. Vishniac takes nature as he finds it, in normal activity and surroundings. He disapproves of the methods generally used by nature workers, who frequently kill, chloroform, or otherwise incapacitate such subjects as butterflies and beetles in order to photograph them under ideal photographic conditions.

Figure 5. Announcement in The Museum, the bulletin of the Field Museum of Natural History, of Vishniac's exhibition Animals in Motion. Featuring 48 photographs of live animals, the article described Vishniac as a "... zoologist who has specialized in hunting by camera.”. Vol. 21, No.10, 1950. Courtesy of The Field Museum

Foundation titled, "Photography of the behavior of socially living insects in free nature”. (Vishniac 1943)

27 August 1945 marked the first appearance of Vishniac's scientific photographs in LIFE magazine, illustrating an article on insect damage to crops executed in collaboration with LIFE's science photography specialist Fritz Goro. (LIFE 1945) Vishniac's first major academic project came in 1946; a study of healing and regeneration in tadpole tails utilizing live subjects with Dr. C. C. Speidel of the University of Virginia (UVA). In this study wounds were made to tadpole tails and Vishniac photographed the cellular processes (e.g.: phagocytosis) leading to blood vessel repair. (Kinkead, 1955A pg. 40) Portions of this work remain preserved in the UVA archives. (Speidel 1946)

By about 1950, Vishniac was able to largely give up his nonscientific work and concentrate all his efforts in the realm of biology. This period, beginning in 1950 and continuing through the early 1970s, comprised Vishniac's most important and prolific years in biological photography and cinematography. Vishniac's work and reputation were well enough known by then that he authored a promotional article titled Color Photomicrography for Exakta, a popular camera manufacturer of the day. (Vishniac 1950) The first known exhibition of Vishniac's scientific photography took place in a monographic exhibit of his work titled Animals in Action which appeared at the American Museum of Natural History (AMNH) in NYC from 8 March to 2 April 1950. (AMNH 1950) The exhibit then traveled to the Field Museum of Natural History (FMNH) in Chicago, IL and was on display 1 October to 31 October. (FMNH 1950) (Figure 5) A second Vishniac exhibition titled The World at Your Threshold, featuring microscopic life found in NYC's Central Park, was shown at AMNH from 5 April to 29 April 1951. (AMNH 1951)

Throughout the first half of the 1950s Vishniac (solo, or in collaboration with other photographers and illustrators) executed major assignments for LIFE. All displayed photographs of living insects, aquatic species or microorganisms. Amongst these, two are of particular prominence. In 1951, Vishniac produced an article describing and demonstrating a photomicrographic technique that he dubbed "Colorization". (LIFE 1951) In the article's text Vishniac described his "novel" methods of adding color to otherwise transparent microscopic specimens, thus helping to elucidate structural differences otherwise difficult or impossible to see. (Figure 6A \& B) The photographs appearing in this article (as well as other still and ciné materials of the period) have previously been described as having been produced using contrast enhancing modalities including darkfield, Rheinberg illumination, polarization and phasecontrast (all of which were extant though not widely known or utilized by photographers) or a combination of these methods. (Radzyner 1993) Vishniac was able to portray and promote "Colorization" as an innovative technology that he pioneered. This well-demonstrates Vishniac's facility for self-promotion; which would serve him well as he continued his work as an independent photographer and producer who was always obligated to seek clients, commissions and grants.

Vishniac - who at this time did not yet have an institutional or academic affiliation - described some aspects of his "Colorization" method in a presentation to the American Society of Zoologists: “... the details of biological structures can rarely be visualized directly in fresh preparation under the polarization microscope. This difficulty has been partially overcome by introducing compensators into the optical system 


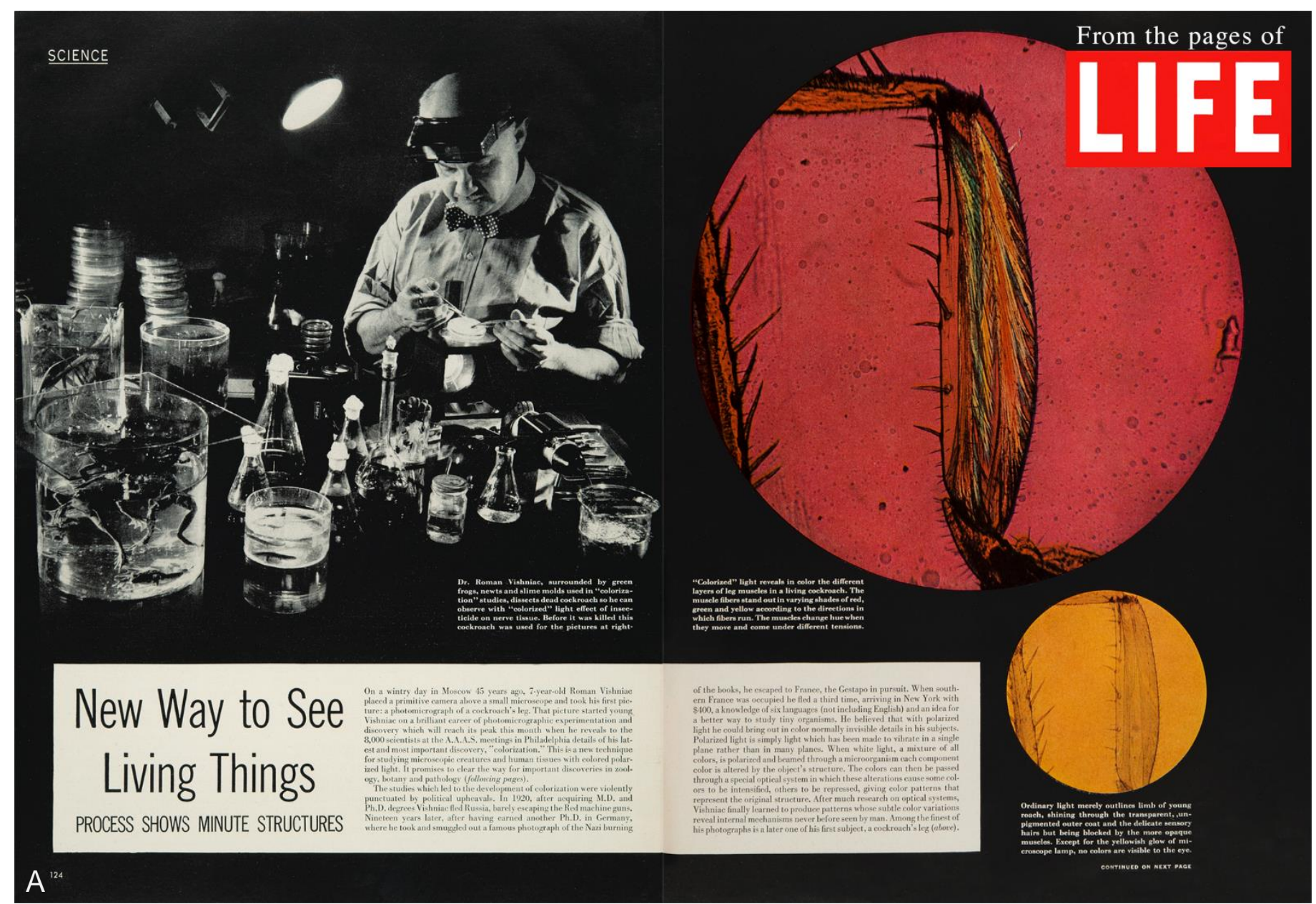

Figure 6 A \& B. New Way to See Living Things. Double-page spreads from LIFE magazine, December 17, 1951.

A: On the left page, a photograph by LIFE photographer Fritz Goro of Roman Vishniac in his NY apartment/lab/studio. On the right page, photomicrographs of a cockroach leg; recreating the Vishniac's first photomicrograph, which he said he had made as a child of 7 years old. Photographed using the "Colorization" technique with comparison to conventional transillumination.

B: Left Columns: Comparisons of conventional transillumination of histologic sections of tissue specimens (left) versus application of Vishniac's "Colorization" technique (right). Right Columns: Application of "Colorization" to living, transparent and semi-transparent specimens.

(C) 1951 Time, Inc. All rights reserved. Reprinted from LIFE and published with permission of Time, Inc. Reproduction in any manner in any language in whole or in part without permission is prohibited.

having specific fractional wavelength retardations. In this manner the weak birefringence is replaced by various chromatic shades of interference colors. The resulting polichromatic (sic) image resolves a structural detail otherwise invisible in the living tissues of plant and animals. By comparison with fixed and dehydrated preparations of the same tissue, one may identify numerous artifacts produced by the customary histological and cytological procedures.”. (Vishniac 1951) He also described this method in later, published interviews. (Kinkead 1955A pgs. 35-38) Noteworthy is Vishniac's consistency in always emphasizing the value of working with living specimens.

Vishniac's second LIFE assignment of especial note, appearing in the issue of 11 February 1952, was a collaboration with Dr. Carroll Williams (who was voted "Young Scientist of the Year" by the American Association for the Advancement of Science) illustrating an article on insect metamorphosis. (LIFE 1952) Williams' work, described and displayed in the article, concerned the effect of hormones on induction of metamorphosis in Hyalophora cecropia, North America's largest moth species. (Figure 7) This work nicely paralleled the research that Vishniac had done earlier as a graduate student in Russia. Vishniac spoke of how his knowledge of endocrinology and endocrine effects convinced Williams to allow the collaboration. (Kinkead 1955A pg. 48) The article and its photographs were also released by Time, Inc. as a 68-frame educational filmstrip accompanied by lecture notes titled Metamorphosis (Library of Congress 1954) in their widely distributed LIFE Filmstrip Series.

Vishniac also undertook extensive projects with Dr. Talbot Waterman (an expert on insect sensory physiology) at Yale University on the visual apparatus of the firefly. After dissection and preparation of the insect's ommatidia (multilensed eye) Vishniac photographed his daughter Mara through the insect eye mounted on to the objective lens of a horizontal microscope. (Kinkead 1955B pg. 46) (Figure 8) With Drs. 


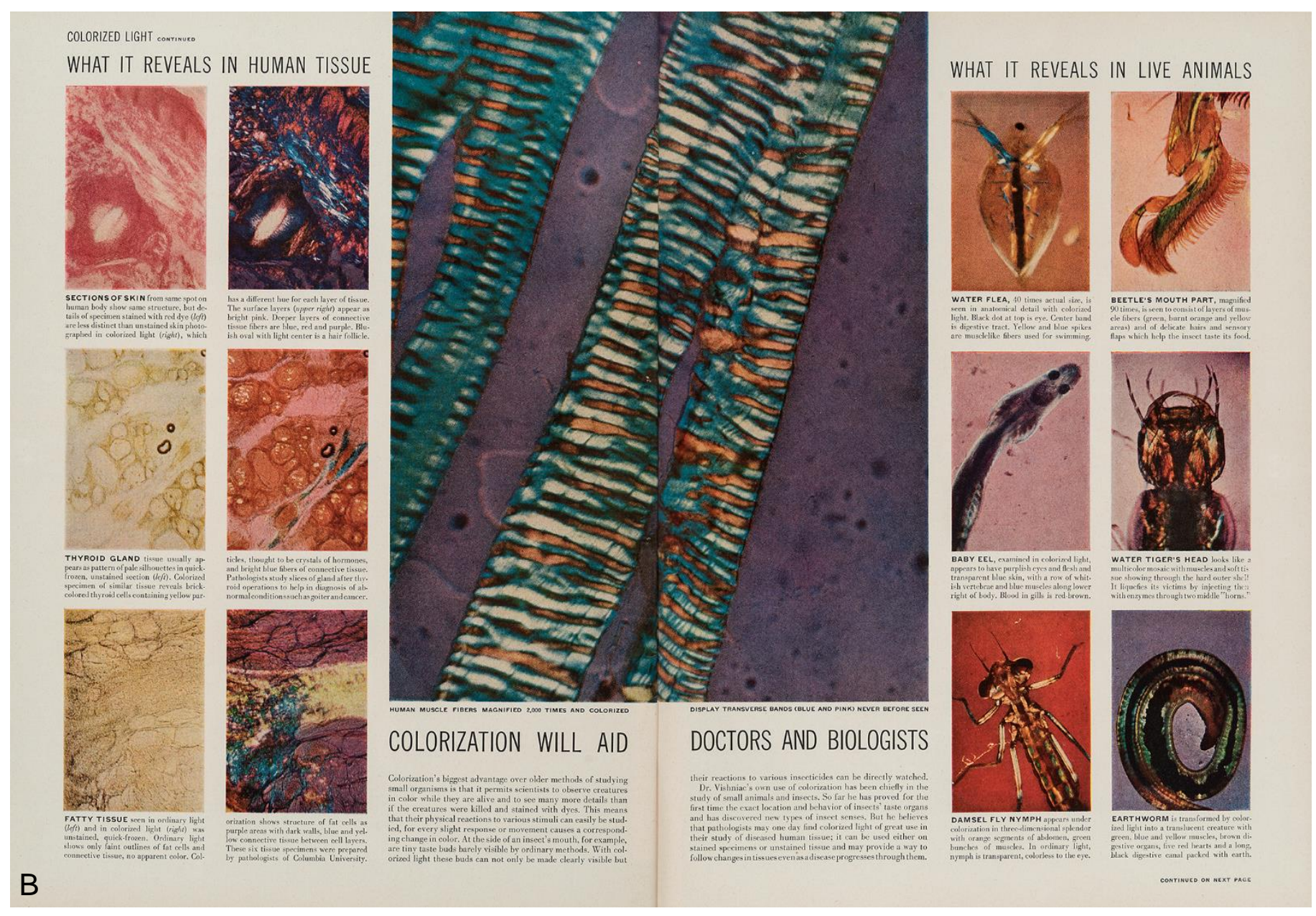

Benton Lutz and George Fulton at Boston University he participated in studies on the repair of blood vessel damage and embolus formation in the cheek pouch of hamsters. Vishniac developed a systematic method of returning to an identical, in vivo, microscopic field over time using the subjects' vascular tree as a "road map" through low magnification to high magnification transitions leading to a particular area of induced vascular damage and subsequent healing and remodeling. (Kinkead 1955A pg. 38, Lutz \& Fulton 1954)

Equally busy working on non-academic projects, during this time Vishniac continued to produce articles for LIFE and other general interest magazines including Collier's, The Saturday Evening Post, Sports Illustrated, Scientific American and Friends. He also produced cinematographic material for various clients. His cinephotomicrography of living aquatic organisms was shown in a 1956 (Warner-Pathé 1956) newsreel produced with well-known cinematographer Karl Malkames (Malkames 1993) (Figure 9) This film also provides a brief glimpse at the facilities and character of the Marine Biological Laboratory at Woods Hole, MA where Vishniac spent many of his summers during his most fertile and productive decades. The network of institutions that developed in this area attracted (and continues to attract) a large group of scientists and researchers with diverse interests who would decamp from their home bases for summers on Cape Cod. Besides lab space and facilities as well as an ocean full of specimen material, this idyllic colony located on the Southwest corner of Cape Cod, provided an environment wherein Vishniac was immersed in biological science. It was in this special community that he worked, studied and developed long-term professional relationships.

Examples of commercial photographic projects that Vishniac undertook during this period contained at RVA-ICP include photographs demonstrating resistance to mildew and rot for Plymouth Cordage Company, a rope manufacturer; and insect photography produced to advertise Sting-Kill@, an analgesic to relieve the pain of insect stings, manufactured by Marion Health \& Safety Corporation (and still available for sale in 2017).

1955 marked a milestone for Vishniac with two major events of professional significance that helped to further propel his career. In July, Vishniac was the subject of a lengthy two-part profile in The New Yorker magazine which was based largely on extensive interviews with Vishniac and others. Authored by Eugene Kinkead (who wrote for The New Yorker from 1933 through 1984) the articles described in great detail Vishniac's extensive scientific photography and which presented and discussed his pre-war documentary photography briefly and principally as a part of his past history. (Kinkead 1955A, Kinkead 1955B) These two articles provide much of the currently extant information regarding Vishniac's work during 
this period. Later in the year he was awarded the Memorial Award for 1955 of the American Society of Magazine Photographers (ASMP) specifically for his scientific work, the citation stating, "In recognition of his brilliant work in the field of scientific photo-macrography (sic) and for showing mankind the incredible beauty of the world it cannot see.". (ASMP 1955)

The profile in The New Yorker, appearing in consecutive weekly issues, brought Vishniac's work to a new and much broader audience and subsequently gave him much greater access and credibility when he later pursued grant support for motion picture projects. Throughout, the articles placed great emphasis on the unique nature of his work with living organisms, on how much personal involvement Vishniac brought to his work (e.g.: gathering and housing specimens, research in to the habits and habitat of subjects) and on the technical processes that he used. Included in a lengthy technical discussion and description are subjects such as the optical considerations of refraction and polarization of light; use of micromanipulators; combined diascopic and episcopic illumination methods; the difficulty of maintaining field-ofinterest whilst observing and filming moving microorganisms; and what we would now refer to as "focus stacking" in order to increase the vanishingly small depth-of-field encountered at high magnification. Maintaining his strong views regarding observation of living subjects, he railed against the relatively new technologies of ultraviolet and electron microscopy which either killed the subject or required dead, fixed material. This rather technical material and its discussion were presented to the readers of a general interest magazine. The New Yorker in 1955 seldom published photographic images in its editorial content (a practice it continues today). Vishniac's and Kinkead's language alone (save for two small line-drawing portraits of Vishniac and brief quotes from comments by others about Vishniac) convey both the technical content and Vishniac's personal attachment to his scientific photography.

Especially prescient is Vishniac commenting on advances yet to be made utilizing light microscopy: "... the future of microscopy lies in extending the range of the study of life ...". (Kinkead 1955A pg. 30) Vishniac could not have predicted advances such as vital staining, fluorochromes and confocal microscopy - all of which we now apply to living material and each of which have indeed extended the range of the microscopic study of life. We suspect that these technologies would not have surprised him and indeed can be seen as further proof of his oft-expressed belief in the importance of experimentation and observation using living subjects. On full display in The New Yorker articles is Vishniac's penchant for storytelling and anthropomorphizing. Included are descriptions of observations through the microscope such as: "Here comes a little animal who is full of curiosity. He wants to learn and see more, and is forever peering around his tiny landscape. Near him is another who is interested only in searching for food. And now comes a third who is more social. He hates to be alone and is constantly running from one friend to another.". (Kinkead 1955A pg. 29) and: “... We see the male bristle worms, circling in the light in a state of wild excitement. Then we see a female approaching, with her peculiar tapering movement. Now the males circle around and around the female, whirling madly closer and closer. And then finally one reaches her, and in the moment of fertilization the female literally explodes scattering the fertilized eggs in every direction. And then more males and more females - over and over again this miracle of life and death occurred before my eyes. Nereides - even more lovely than their name!". (Kinkead 1955B pg. 52)

Vishniac was often criticized for this unscientific, even Romantic, manner of description. Criticism on this matter came in correspondence even from his own son - Dr. Wolf Vishniac - who was by this time a prominent academic microbiologist. (Vishniac, W. 1961) However, Romantic descriptions were (and perhaps remain so today) a highly useful and effective tool for expressing delight in the subject, engaging the audience or reader and developing a narrative. This skill would serve Vishniac well as the 1950s drew to a close and he entered the next phase of his career, independently producing books and films aimed at biology education for students and the general public.

Equally useful to Vishniac in developing and producing projects was the enormous number of contacts in his network of colleagues and friends. Vishniac was a member, and/or fellow of many professional and scientific organizations including the: Biological Photographic Association (now the BioCommunications Association), New York Academy of Sciences, New York Entomological Society (for which he served as President in 1955 and 1956), New York Microscopical Society (where he regularly taught), American Society of Protozoologists and the National Association of Biology Teachers. Additionally, as evidenced by the voluminous correspondence in his archive, Vishniac maintained relationships with a vast number of subject matter experts at colleges, universities, corporations and government agencies in the US and abroad.

Addressing a general audience, Vishniac authored the text and provided color photography for two booklets, The Living Earth (Vishniac 1956) and Mushrooms (Vishniac 1957A), which were part of the National Audubon Society's Nature Program (in collaboration with the publisher Nelson Doubleday, Inc.). Audubon's multi-volume educational series was aimed specifically at the youth market. Each booklet was accompanied by photographs on a perforated sheet of color "stamps" (42 accompanying the Mushrooms title and 30 accompanying The Living Earth) which the young reader would paste to the pages describing the pictured subject. This was an economical method of adding color images to printed matter. (Figure 10) Mushrooms was re-issued in 1966. (Vishniac 1966a) It bears noting that these publications and other accomplishments took place within Vishniac's first 15 years in NYC; having been engaged exclusively in biological photography for about only 5 years.

While Vishniac continued to work in still photography until the end of his career, at about this time, loosely the late-1950s, his major interest and efforts moved into the motion picture world. As early as November 1956, (Vishniac partnering with researchers at the Roswell Park Memorial Institute in Buffalo, NY) submitted a grant application to the National Institutes of Health (NIH) for funding to investigate applications of 


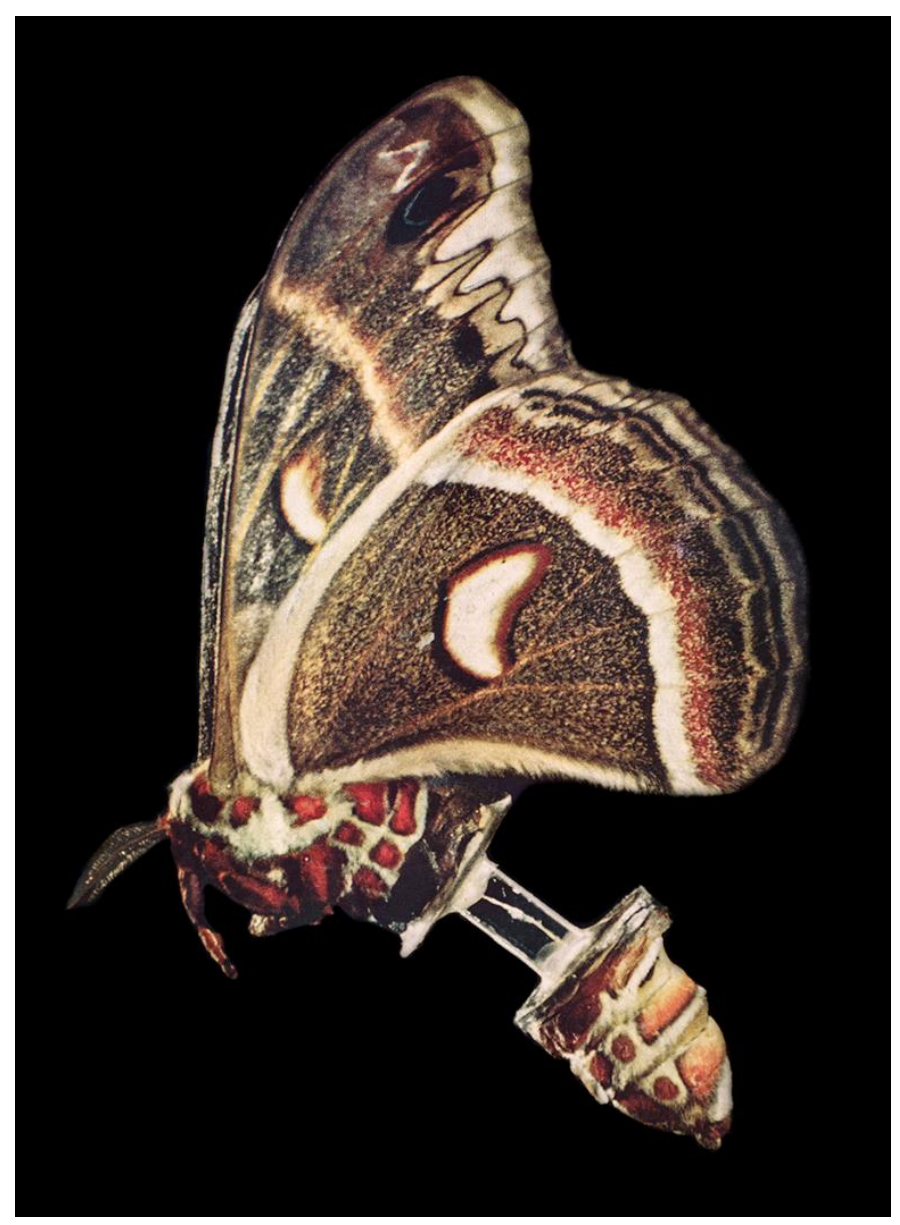

Figure 7. The abdomen and thorax of Hyalophora cecropia separated and connected by a glass tube, illustrating early experiments on the chemistry of metamorphosis in collaboration with Professor Carroll Williams from the Biology Department at Harvard University, 1951. (C) Mara Vishniac Kohn, Courtesy International Center of Photography.

cinematographic technology to cancer research. (Hauschka 1956) Working commercially, Vishniac was commissioned by Disney Studios to produce footage of aquatic microorganisms used in Secrets of Life, a theatrical-release feature film. (Disney 1958)

In the late 1950's Vishniac began a collaboration lasting in to the late 1960s with Dr. Philip Sawyer on the vascular process of mesenteric thrombosis at the State University of New York's Downstate Medical School. (Figure 11) This collaboration involving both still and ciné imaging resulted in one of the few academic publications credited to Vishniac. (Vishniac 1965) Sawyer later wrote of working with Vishniac during this period: "He wanted to do elegant motion pictures of microscopic biological activity .... We would look through the microscope again and again, deciding that we did not like what we saw. Finally, we would photograph a beautiful vision of something that was going just right and was properly illuminated ...". (Sawyer 1990) Vishniac's collaboration with Sawyer produced a film which in 1961 was awarded First Prize at the $25^{\text {th }}$ Annual Congress of the International Scientific Film Association meeting in Rabat, Morocco. (NSF 1961)

In 1958 the Educational Testing Service (ETS) based in Prince- ton, $\mathrm{NJ}$, utilizing film material supplied by Vishniac (as well as commentary by him) produced a biology education film directed to secondary schools titled The Worlds of Dr. Vishniac. (ETS 1958A) The film was accompanied by a printed classroom study guide. (ETS 1958B) This film was part of the ETS' Horizons of Science series which was produced with support from the National Science Foundation (NSF). (Figure 12) It is possible that the collaboration on this film series with ETS provided the impetus for Vishniac to develop his concept for what became his major cinematographic effort, the Living Biology Film Series, as well as helping to identify a potential source of funding for such an educational production.

Vishniac was appointed a Research Associate in the Department of Anatomy at Yeshiva University's (YU) Albert Einstein College of Medicine (AECOM) in May 1957. By June 1957 he had submitted a grant proposal to NIH through AECOM requesting $\$ 57,592$ in funding to investigate "Color Cinemicroscopy at High Magnifications and its Application to the Study of the Circulatory System of Protista". (Vishniac 1957B) No available records indicate whether either this proposal or the earlier proposal written in partnership with Roswell Park were funded.

Further evidence of Vishniac's pursuit of grant funding comes in a letter to Vishniac (in response it seems to a query from Vishniac) from Dr. John T. Wilson, Assistant Director for Biology and Medical Sciences at NSF (and later President of the University of Chicago) encouraging Vishniac to submit a project application, saying: "I am familiar with your work and have seen the LIFE pictures as well as having read The New Yorker article on you ... we have no forms to fill out resting merely on the write up of the individual making the proposal.”. (Wilson 1957)

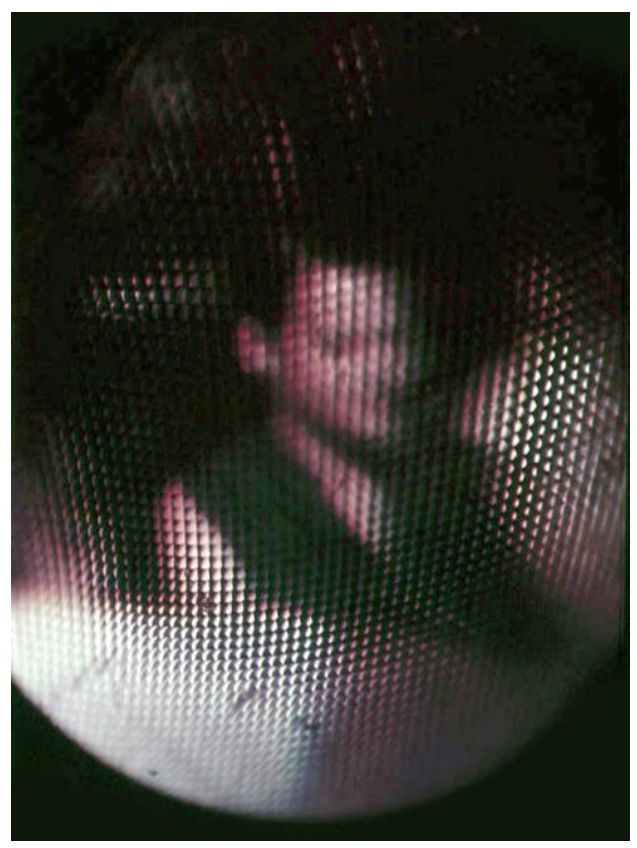

Figure 8. Roman Vishniac's daughter, Mara, as seen through a firefly's eye, ca. 1952. Courtesy University of South Carolina Libraries, Moving Image Research Collection. 


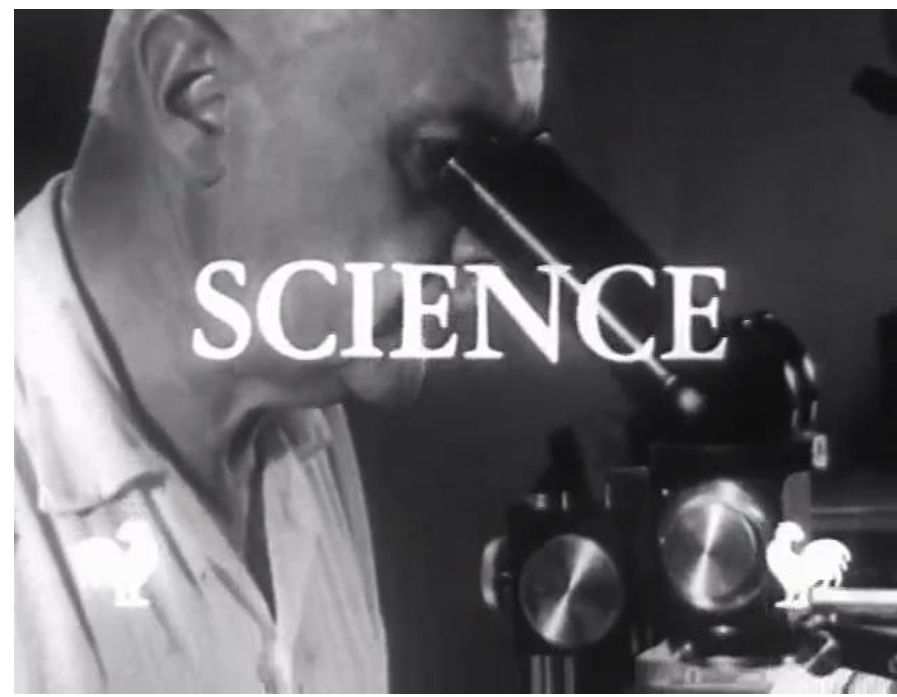

Figure 9. Warner-Pathé News, News Magazine of the Screen (Vol. 7, Issue 4). Newsreel report of Roman Vishniac's work. 1956 (Click image for video.)

On 28 December 1959, closing an eminently successful decade, Vishniac submitted "A Proposal to the National Science Foundation for a Living Biology Film Series" with YU as the sponsoring institution. (Vishniac 1959) The Living Biology Film Series as detailed in the proposal was to initially consist of eight films for high school use and five for college level. An additional 16 films were proposed for high schools and eight additional for colleges to be produced in a second phase. Vishniac's approach to this project described in the grant proposal retained his guiding precept of working with living subjects: "There is a need for a new approach, namely, a series of films which come as close as possible to duplicating the experience of an original observer so that the student can see for himself the life processes from which current theories and established fact have evolved ... In general all filming will be done in those geographical areas which are the natural habitats of the living organisms to be studied.". The "Major Areas" the series proposed to address could still today form the core of an undergraduate biology survey course. (Table 1)

Table 1: "Major Areas" Identified in 1959 Living Biology Film Series Proposal to the National Science Foundation

Units of Life (protoplasm and cells)

Origin of Life (Evolution)

Heredity (Genetics)

Structure and Function of Nature (Ecology)

The Plant World

Structure and Function of Organisms (organs, systems, etc.)

\section{United States $(1960$ - 1975)}

On 8 June 1960, six months after the proposal's submission, the National Science Foundation dispatched a funding letter to Yeshiva University's President (Dr. Samuel Belkin) awarding "...the amount of $\$ 112,340$ for the production of a first group of films in the projected "Living Biology" series" ("NSF G13097'). Funding was issued via the Course Improvement Program of the Curriculum Improvement Section. The funding letter states, hewing closely to the language of the grant proposal, "The general purpose of this project is to help improve instruction in biology in secondary schools and colleges and universities by producing a series of $16 \mathrm{~mm}$, soundcolor motion pictures designed to duplicate for students as closely as possible the experience of original observers in studying organisms in their natural environments so that students can see the dynamic living processes upon which current interpretation and theory are based.”. (Kelly 1960)

It might be difficult, close to 60 years later, to appreciate or overestimate the importance and distinction of such a prestigious grant (as well the prospect of income that the project's films might generate) to a small, relatively young institution. Yeshiva College had been established in 1928 and was elevated to university status in 1945. The university's medical school was opened in 1953. Correspondence in YU's archives demonstrates that this project received attention at the very highest levels of the institution; often involving the university's President and General Counsel as well as its financial and public relations offices. The grant was sufficiently newsworthy to be reported by the NYT on 22 August 1960 stating; "... Vishniac believes that looking at a dead organism on a microscope slide has the same limitations as studying anthropology by looking at cadavers under glass. He promises to capture on educational film the true-to-life behavior of living organisms.". (Hechinger 1960) Recognizing the importance of the grant, in 1961 YU appointed Vishniac as Professor of Biology Education; which was a joint appointment held in its Graduate School of Science and Graduate School of Education. (Belkin 1961) In June 1962 a two year extension grant in the amount of \$143,050 was funded by NSF ("NSF-G13097

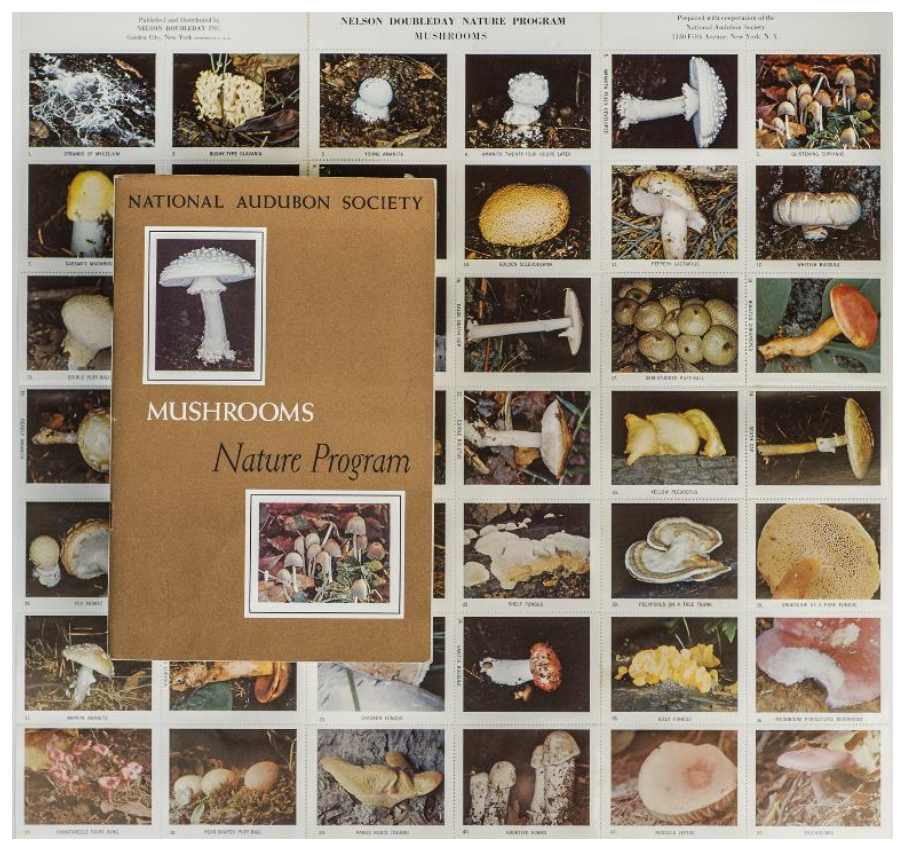

Figure 10. Mushrooms. A booklet from the National Audubon Society Nature Series with accompanying four-color stamps (Vishniac 1957) By permission of Audubon and courtesy of Penguin-Random House. 

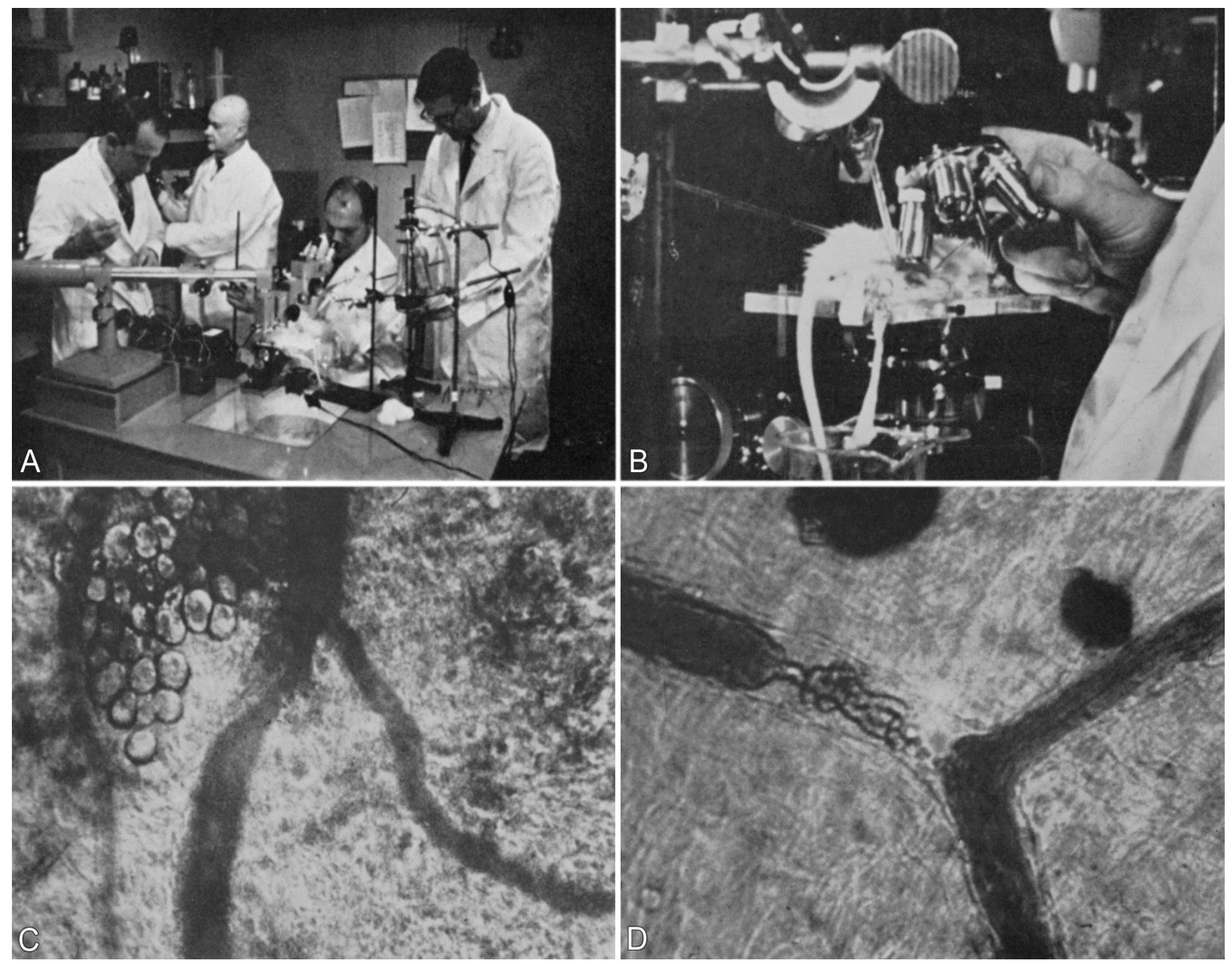

Figure 11 A-D. A figure from Roman Vishniac's chapter Effects of Small Electric Currents and Dying Tissue on Blood Flow in The Rat Mesenteric Blood Vessels from the Biophysical Mechanisms in Vascular Homeostasis and Intravascular Thrombosis, edited by Philip Sawyer, 1965.

A \& B. Surgical laboratory and preparation of an anesthetized rat on a specially designed microscope stage for application electric charge to the mesentery. In 9A, Vishniac second and Sawyer third, from left. C. Normal vascular flow, x200. D. Completely occluded vessel in the center of the mesentery, x200.

Courtesy Estate of Phillip N. Sawyer.

Amendment No. 1"). (Scherer 1962) The total funding received by Vishniac for the Living Biology project (including a small travel grant received in 1961) was equivalent to a 2017 dollar value of approximately $\$ 2,086,892$.

Documents in the YU archives record extensive discussions regarding administrative and business related issues pertaining to the film series: Should the films be rented or sold? Should distribution be in-house or should it be contracted out? To what use(s) would YU be allowed to put any income accruing from the films? At one point, the possibility of a total of 75 films with a production budget of over $\$ 1,000,000$ was under discussion. (Conal 1962) After receiving several proposals YU assigned the distribution of the Living Biology films to the McGraw-Hill Publishing Company's educational division which had an established network designed to manage audiovisual materials.
Other discussions documented in Yeshiva's archive included: selection of a narrator, retaining of a scriptwriter (identified only as a "Miss Greenberg") and establishment of an Advisory Committee. The Committee was to be chaired by Dr. Carroll Williams with whom Vishniac had previously worked on a major LIFE article described earlier (and who was at this time Chairman of Department of Biology at Harvard University). Committee members included faculty from the Universities of Georgia, Tennessee and Rochester, City College of NY and AECOM.

Owing to its innovative nature (and perhaps as well to Vishniac's inexperience with bureaucratic process) production of the Living Biology project was not without its difficulties and the project never grew to its discussed potential. A third funding application to NSF was rejected. While the project concluded in 1964, correspondence anent its issues continues in YU's archives until 1967. 
No review of Roman Vishniac's professional life would be complete without an acknowledgement of the role that his second wife, Edith (to whom he was married in 1947) played in his success. Edith Vishniac was de facto lab assistant, organizer, specimen wrangler and even projectionist for her husband's lectures. Edith's crucial support and contributions did not go unrecognized. In The New Yorker's profile Vishniac relates (at length) how Edith was able to coax a sea bass in to a feeding position, allowing him to photograph the fish consuming a squid; behavior that had never before been documented. (Kinkead 1955B pg. 45) The photograph of this event was featured as a full page picture in a 1953 LIFE article titled Creatures of the Sea. (LIFE 1953) Edith was also prominently credited in the films her husband produced and she received an assistant's salary from the grants for the Living Biology Film Series when this was in production.

\section{Table 2: Completed Living Biology Films*}

\section{The Living Tide ( 3 parts)}

The Rocky Shore (The Living Tide, Part 1)

Brim of Sand (The Living Tide, Part 2)

The Edge of the Sea (The Living Tide, Part 3)

\section{The Pond (3 parts)}

Standing Water (The Pond Part, 1)

Animal Life in Fresh Water (The Pond, Part 2)

Distribution of Energy in the Pond (The Pond, Part 3)

The Microscopic Plants: Algae (Originally intended as a multi-part film; only one part was completed)

* Released in 1968 and distributed by McGraw Hill Publishing. (All films are held in the collection of The University of South Carolina, Moving Research Center)

In 1994 156,000 feet of cinematographic materials, much of it from the Living Biology series, were presented by Vishniac's estate to the University of South Carolina's Moving Image Research Center (USC-MIRC) creating the Roman Vishniac: The Subject is Nature collection. Included in the collection are extant copies of the Living Biology series as well as out-takes, experimental materials and personal movies along with a small amount of still photographic material. (Also included and available via digital access at USC-MIRC is the small amount of Vishniac's pre-war cinematographic material that found its way to the US.

While Living Biology was certainly his major effort during the 1960s, Vishniac's work was not limited to that project. Pharmaceutical clients during the 1960s included (among many others) Abbot Laboratories, Bristol, Meyers \& Co., Pfizer Incorporated and The Upjohn Company. For Roche Laboratories, US branch of F. Hoffman-La Roche Ltd., Vishniac was asked to provide photographs of the newly introduced benzodiazepene compounds Librium ${ }^{\circledR}$ (Chlordiazepoxide) (Gulick 1962) and its subsequent analogue Valium ${ }^{\circledR}$ (Diazepam). (Lerner 1964)

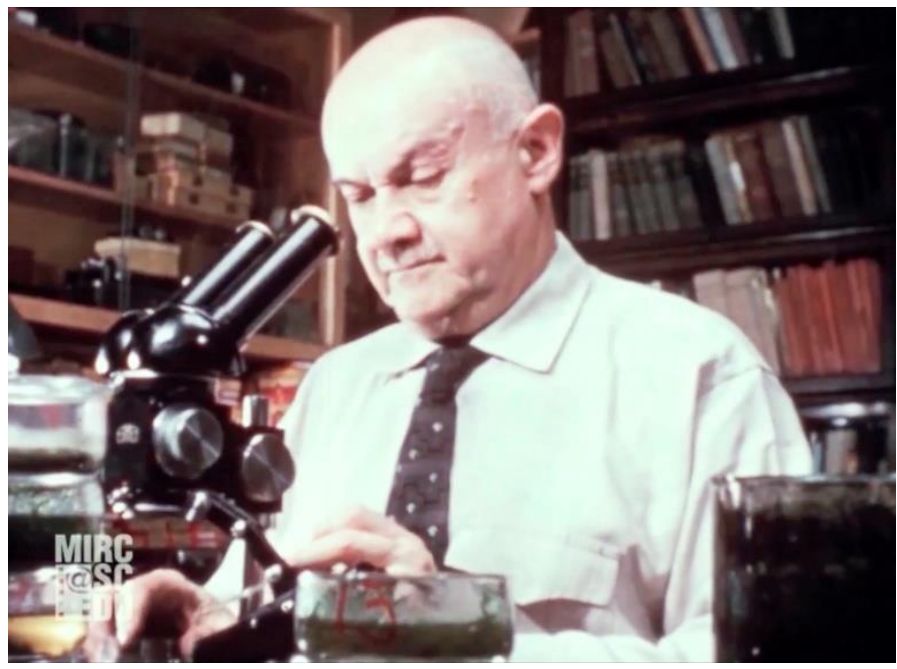

Figure 12. The Worlds of Dr. Roman Vishniac, Horizons of Science, Vol. 1, No. 2, 1958. (Click image for video.)

(C) 1960 Educational Testing Service. Princeton, NJ. All rights reserved. Portions of this video reproduced by permission of Educational Testing Service, the copyright owner. All other information contained within this article is provided by the author and no endorsement of any kind by Educational Testing Service should be inferred.

A 1963 Shell Oil Company advertisement in LIFE presented a Vishniac photomicrograph across a two-page spread ("doubletruck" in magazine jargon). (The Shell Companies 1963) Exceptionally unusual for its time, this advertisement provided the photographer a credit line; further attesting to the perceived value and prominence of Vishniac's work. During this period (and onward) his work also appeared in advertisements and promotional materials produced by Eastman Kodak, Polaroid, Arriflex and IBM. As well, RVA-ICP is replete with correspondence, solicitations, proposals and contracts regarding Vishniac authoring or co-authoring photography and biology texts. Some of the publishers represented in this mass of material include: McGraw Hill, Harcourt Brace, Simon \& Schuster and WW Norton. None of these publishing projects were brought to fruition.

Over a 27-month period (1966-1969) Boy's Life magazine featured a series of four multi-page articles on use of the microscope and the world of microorganisms by Vishniac. (Vishniac 1966b, Vishniac 1967a, Vishniac 1967b, Vishniac 1969) Vishniac provided both writing and photography for these articles, which were addressed to the youthful readership of this magazine. Boy's Life which was (and is still) published and distributed by the Boy Scouts of America to its members and leaders, had a 1969 circulation and readership in excess of 6,000,000. (Barber 1972)

Further peer recognition came to Vishniac from ASMP with election in 1967 to its Honor Roll, in recognition of career-long achievement. On the evening of 28 May 1968 (7:30 PM Eastern/6:30 PM Central) NBC News broadcast The Big Little World of Roman Vishniac. This 52-minute (i.e.: the standard broadcast-hour) documentary presented Vishniac and his photographic and cinematographic imagery in biology using footage of Vishniac at work, as well as material that he himself 
had filmed, in a national, prime-time, network special. (Library of Congress 1969) The following year the broadcast was nominated for an Emmy Award in the Outstanding Cultural Documentary category. (Broadcasting 1969) 1968 may be regarded as the last point at which Vishniac's renown was based essentially solely on his work in biological photography.

In 1969 a small selection of Vishniac's pre-Holocaust photographs were used as illustrations in A Day of Pleasure: Stories of a Boy Growing Up in Warsaw. Written by Isaac Bashevis Singer (1978 Nobel). This collection of short stories was the winner of the 1970 National Book Award for Children's Books and its publication marked the first significant appearance of Vishniac's documentary photography since 1947; helping to ignite interest in this aspect of his photographic work and providing it recognition alongside his now renowned biological photography.

1971 marked a watershed for Vishniac both in the realm of his scientific photography and in the emergence of his documentary photography as a subject of serious consideration in the photographic art community. During this year Vishniac's work was presented in a national television commercial; he published a book of photomicrographs; and his work - both scientific and documentary - was displayed in his first monographic museum show since that at the American Museum of Natural History in 1951.

Georgia-Pacific Corporation as part of an ongoing marketing campaign promoting disposable, paper Dixie Cups ${ }^{\circledR}$ as a healthier and more sanitary alternative to the conventional shared cup or glass commonly found in household bathrooms, produced a 30-second, broadcast television commercial utilizing in vitro cinephotomicrography provided by Vishniac. The ciné footage displayed the fearsome and potentially harmful "... live microorganisms ..." that might be found on such a cup despite the household's best efforts at cleaning. The voice-over narration credits the footage to "... Roman Vishniac,

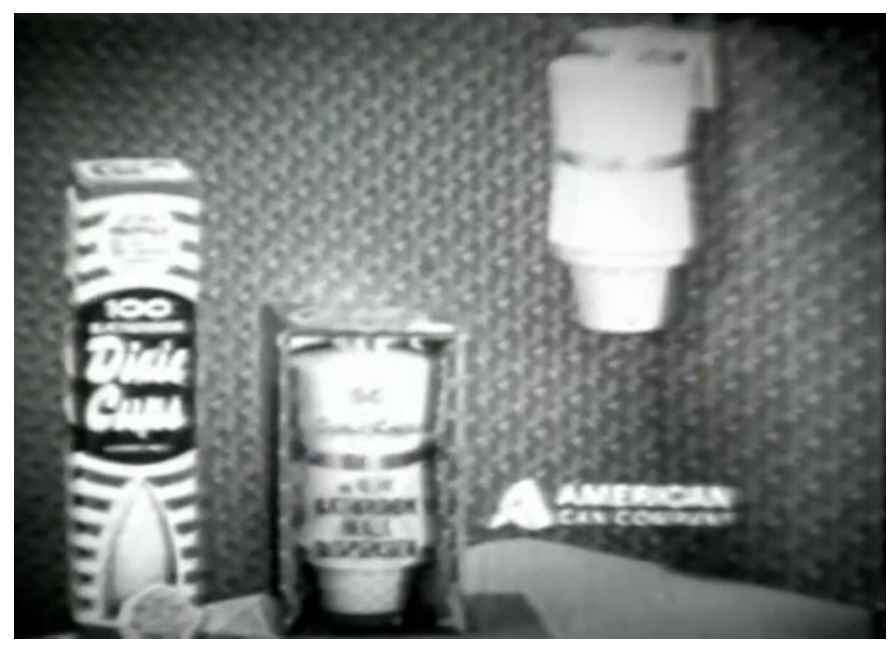

Figure 13. 1971 major-market television commercial, produced by Georgia-Pacific, promoting disposable Dixie ${ }^{\circledR}$ Bathroom Cups utilizing Vishniac's in vitro cinephotomicrography of live microorganisms. (Click image for video.) Courtesy of Georgia-Pacific, LLC the world's leading authority on photomicrography ...". (Figure 13) Vishniac discussed the production of this commercial with colleagues at the BPA's 1974 meeting in NYC emphasizing that this was the first appearance in a television commercial of this type of footage. (Radzyner 2016A)

BUILDING BLOCKS OF LIFE Proteins Vitamins and Hormones Seen Through the Microscope with photographs and text by Vishniac was published as a volume in the series "Scribner Portfolios in Natural History". (Vishniac 1971) This slim book consists of half-, full-, and double-page reproductions of polarized light photomicrographs of crystals of the compounds essential to life. Vishniac's accompanying essays provide information about the compounds and the science related to their discovery and functions.

This book is Vishniac's most self-consciously published artistic effort in the scientific realm: "The pictures in this book ... demonstrate the startling similarities between living cells seen through an interference microscope and the canvases of an abstract painter ... To watch colors change through polarization, changes of phase, and differentiation by interference is an unforgettable experience ... The combinations of colors are artistic, not natural ... the microscopist who is artistically minded is able to create compositions of infinite variety.", (pg. 7) and "...this survey can do no more than provide an introduction to life's building blocks, but it has served its purpose if it has shown that proteins, vitamins and hormones are as essential to life as they are beautiful ..." (pg. 47). Recalling his earliest days in a Moscow laboratory, Vishniac mentions his own work researching the effect of thyroid hormones and that similar research was conducted and published by J.F. Gudernatsch (pg. 46), a Cornell University Medical College researcher, while working in Prague during approximately the same period. (Luck 2014)

On 19 October 1971 the first major retrospective exhibit of Vishniac's photographic work opened. Mounted by the International Fund for Concerned Photography at NYC's Jewish Museum, The Concerns of Roman Vishniac: Man, Nature and Science included 168 color and black-\&-white prints. As suggested by its title the exhibit gave prominence to both the documentary and scientific images that Vishniac had created. Fifty-seven (34\%) of the prints on display depicted biological subjects. (ICP-RVA c.1990) The print exhibit was accompanied by a 32-projector multi-image presentation about Vishniac's biological photography titled Roman's Legions which was produced by Emmy \& Peabody award-winner Craig Fisher. While the exhibit was not accompanied by a formal catalog, a printed program was produced. The cover of the program displayed a 30:1 rendering of a mosquito eye by Vishniac. (Figure 14) The program presented eight biological photographs and eight documentary photographs and included two essays about Vishniac and his work written by Michael Edelson. Edelson, who had known and worked with Roman and Edith Vishniac for more than a decade, was at the time was Executive Editor of Popular Photography, the world's largest circulation photography publication. Concurrent with the exhibit a television special titled The Concerns of Roman Vishniac was produced and broadcast by $\mathrm{ABC}$ News and a 
selection of photographs reflecting the breadth of Vishniac's work was featured in Infinity magazine which was published by ASMP. (Edelson 1971) The content of the exhibit and these related media clearly demonstrates that at this point, there was equal recognition of Vishniac's photography in two complementary spheres - biological and documentary. The exhibit travelled widely in the US and Europe. The next year, Vishniac's documentary photography was included in the highly influential Concerned Photographer series alongside the work of eminent photojournalists Ernst Haas, W. Eugene Smith, Bruce Davidson, Gordon Parks and others. (Capa 1972) As a follow-on to the 1971 exhibit, in 1974 ICP published a volume devoted to Vishniac in its Library of Photographers series. The book was based on edited versions of the 1955 articles from The New Yorker and a selection of photographs from the 1971 ICP exhibit. (Capa 1974) (These articles had also previously been reprinted in a trade-published collection of biology-related articles that Kinkead had written for The New Yorker titled Spider, Egg, and Microcosm: Three Men and Three Worlds of Science. In addition to Vishniac, this collection featured the work of Alexander Petrunkevitch, an arachnologist and Alexis Romanoff, an embryologist.) (Kinkead 1955C) Of the 70 Vishniac photographs appearing in the ICP book, 29 $(41 \%)$ were of biological subjects; an even higher representation than in the preceding exhibit; again recognizing

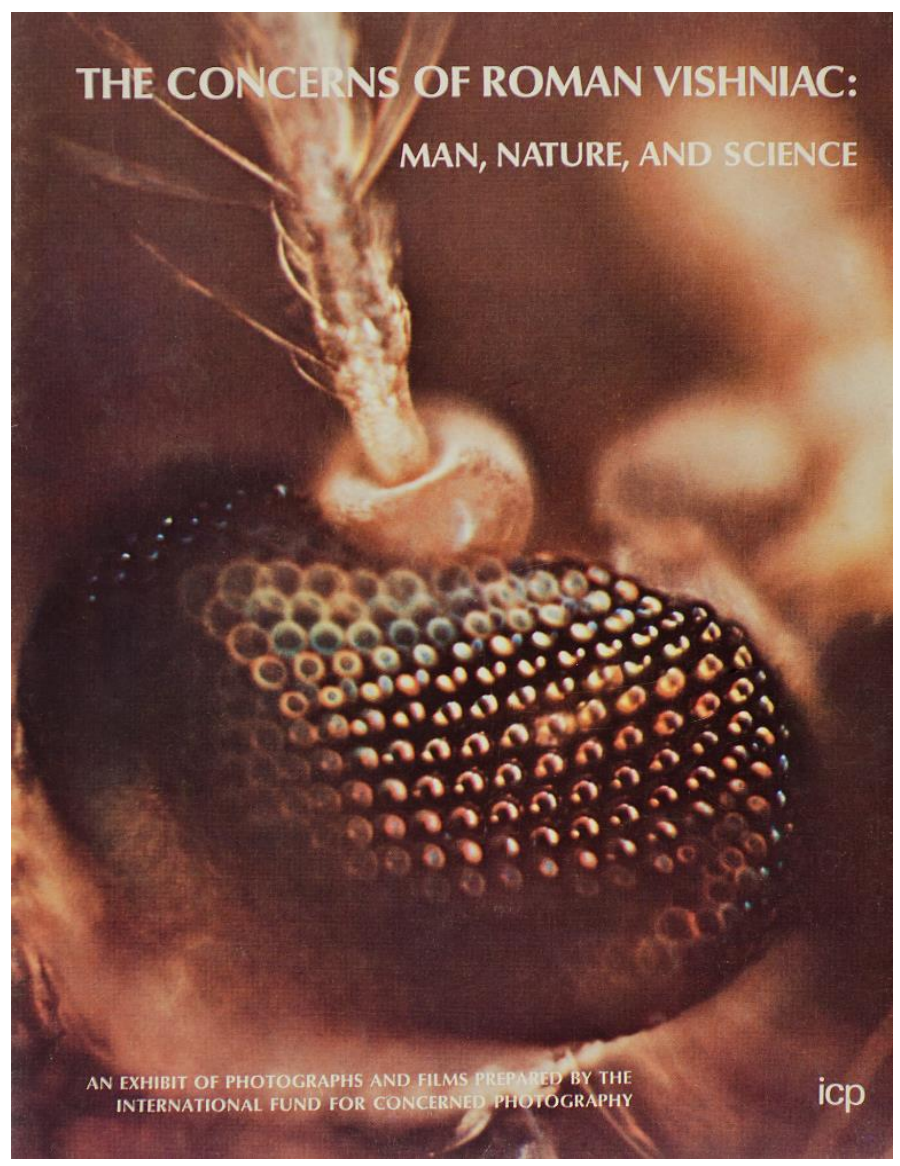

Figure 14. Exhibition Program: The Concerns of Roman Vishniac: Man, Nature \& Science, 1971. Presented by the International Fund for Concerned Photography at The Jewish Museum, New York, NY (C) International Center of Photography. the importance of his work in biology alongside the importance of his documentary photography.

\section{United States 1976 - 1990}

During the latter 1970s and into the 1980s, despite advancing age Vishniac, maintained an active professional life. Also during this time period, Vishniac continued to receive extensive recognition for his work. He lectured widely on a number of topics and was the recipient of many honorary degrees. (Those of particular interest to visual art and communications include: Rhode Island School of Design 1976, Pratt Institute 1978, School of Visual Arts 1984.)

The 12 July 1976 cover of TIME magazine featured a Vishniac photograph of a cicada killer wasp (Sphecius speciosus) to accompany the issue's cover story: The Bugs are Coming. (TIME 1976) This photograph, or one virtually identical, had previously appeared in a LIFE article The World of Insects, (LIFE 1955) in the 1971 ICP exhibition, and later in ICP's 1974 Vishniac monograph. The caption relating to the photograph in this monograph noted that the image was created with an exposure of $1 / 75,000^{\text {th }}$ second. (Capa 1974 pg. 11) Based on correspondence found in RVA-ICP (Edgerton 1959) and in the archives of Dr. Harold E. Edgerton (Edgerton 1957-1961), and given the rarity in the 1950s of equipment capable of producing such a short exposure, we hypothesize that this image was created in a collaboration between Vishniac and Edgerton. Edgerton, a long-time faculty member at the Massachusetts Institute of Technology refined the high-speed photographic "strobe" and produced many memorable still photographs of high-speed phenomena. Both men often spent summers working in Woods Hole and archived letters contain discussions regarding their common interests and that they had sought opportunities to work together. This third appearance in print must have been a "stock" sale - once again evidencing that Vishniac continued to function as an independent, working, professional photographer.

The premier issue of OMNI magazine (a science-oriented, general audience publication) appearing in October 1978 included a 10-page article which included an extensive interview with Vishniac and five full-page reproductions of photomicrographs. (Sabin 1978) Vishniac returned to his recurring discussion of the importance of observing and examining live rather than dead subjects. Commenting on the utility of studying " ' ... a prepared slide of a flat, dead object ..., " Vishniac stated: " 'It is also bad science because dead matter does not teach about life.' ".

1979 brought a second ABC-TV special, the Golden Lens Award of the American Science Film Association and the Eastman Kodak Gold Medal Award from the Society of Motion Picture and Television Engineers which read: “... presented to Dr. Roman Vishniac ... who has substantially advanced the technology and techniques employed for cinemicrography /macrography and used them brilliantly for both scientific research and general education." (SMPTE 1980) In 1982 he presented "Vishniac's Vision: A Veneration of Life" as the 
William A. Reedy Memorial Lecture in Photography - a series endowed by the Eastman Kodak Company - at Rochester Institute of Technology.

ICP presented its second major monographic Vishniac exhibit, A Vanished World, in November 1983 (which toured in the US and internationally through 1988). Shortly preceding the opening of the exhibition, Farrar Strass \& Giroux published a correspondingly-titled, large format, award-winning, "coffeetable" volume of images from Vishniac's pre-Holocaust photography. (Vishniac 1983) The exhibit displayed 60 images culled from the 200 in the book. (Mitgang 1983)

This book and exhibition - as the most prominent and wide communication of Vishniac's pre-Holocaust photographs perhaps marked the closing of the era of Vishniac's renown as a scientific photographer. Neither the tremendously impactful book, which became a best-seller; nor the exhibition featured a single scientific image. This complete omission of Vishniac's decades of work in biological photography cemented the view - in the photography and arts community - of Vishniac as documentarian. In 1984 Vishniac became the third photographer elected to membership in the American Academy of Arts \& Letters (AAA\&L). (Modeled after the Académie Française, AAA\&L is the Congressionally-chartered honor society for the US's leading artists.) The nomination to AAA\&L membership originated from the author I.B. Singer. Seconding the nomination were the painters, Rafael Soyer, Jack Levine and Peter Blume. (Hersey 1984)

The final project utilizing scientific photography by Vishniac (that we have been able to identify) appeared in 1985 in a multipage photo essay titled The Sight of Scents in the November issue of Town \& Country magazine. (Town \& Country 1985) Featuring six polarized light photomicrographs described as "Colorizations"; the pictures of crystals precipitated from luxury perfumes were displayed in a luxuriously spacious design with individual images covering as much as one-andone-half pages. (Figure 15)

Roman Vishniac succumbed to colon cancer on 22 January 1990 at age 92 . The next day in an extensive obituary, NYT once again quoted Vishniac as saying, as had been his credo for many years (as first reported by NYT 32 years earlier (Hechinger 1960)): "You can't teach biology with a bottle containing dead animals and organisms.". (Shepard 1990) An appropriate epitaph.

\section{Coda 1990 -2015}

Vishniac's documentary photographs continued to gain further prominence after his death as the focus of numerous posthumous books and exhibitions. Prominent among these are: To Give Them Light: The Legacy of Roman Vishniac (Wiesel 1993); Children of a Vanished World: Photographs by Roman Vishniac a book (Vishniac Kohn \& Hartmann Flacks 1999) and exhibition that opened initially in NYC in 2000 before touring; and Roman Vishniacs Berlin a 2005 exhibition at the Jüdisches Museum Berlin with accompanying catalog (Fraser, et al.
2005). These exhibitions and volumes were limited to Vishniac's documentary photography and included no display of (and little if any mention) of his biological photography.

In 2007, Mara Vishniac Kohn, Roman Vishniac's daughter and the executrix of his estate, placed the entire collection of her father's photographic images (including negatives, slides and prints), correspondence, ephemera and archival materials at the International Center of Photography in NYC establishing the Roman Vishniac Archive under the supervision of curator Maya Benton. The extensive research that the cataloging and digitizing of Vishniac's entire body of images and other items (totaling over 50,000 objects) facilitated and encouraged resulted in a new and wide-ranging evaluation and appraisal of the diversity of Vishniac's work by scholars. This effort culminated in ICP's third major Vishniac exhibition: Roman Vishniac Rediscovered which opened 17 January 2013 (closed 5 May) and which continues to tour in Europe and the US.

Sadly, despite its broad scope, this exhibit too gave relatively little attention to the major component of Vishniac's life's work. Despite the vast amount of biological photography that Vishniac had created and that was available, and despite the fact that this material had not had a new exhibition since 1971, the exhibit provided only limited attention to this work. In its initial appearance in NYC this consisted of a digital "slide show" of approximately 90 images. In its review, the NYT noted “. $\ldots$ in later decades he concentrated on what will be the biggest revelation for viewers who know his only "Vanished World" pictures: a professional career in photomicroscopy (sic). In a small, dark side room you can view a slide show of digitized photographs of microbes, crystals and other tiny things that he made from the 1950s to the late '70s.". (Johnson 2013)

In 2015 a beautifully-produced, definitive scholarly book sharing the title and paralleling the content of the exhibition was published. (Benton 2015C) Of 22 essays contributed to this work, only a single one discussed Vishniac's decades of biological photography. (Barker 2015A) At a day-long symposium sponsored by ICP and the Center for Jewish History held in NYC on 25 October, coinciding with this book's publication, only one of 20 presentations discussed Vishniac's long career in biological photography. (Barker 2015B)

\section{Discussion}

In our introduction to this paper we introduced the paradox: Why has Vishniac's scientific photography and cinematography - despite the scope and prominence abundantly demonstrated above - largely been forgotten while his humanistic, documentary photography remains a vital art world interest? A definitive answer to such a broad and classic question, of course, cannot likely be provided. Here, rather, we can present no more than speculation and discussion.

A portion of the blame for the disparity in the awareness of and regard for Vishniac's scientific photography versus his documentary "art" may be set at the feet of the sciences and scientists themselves, of whom it may be said that they possess 


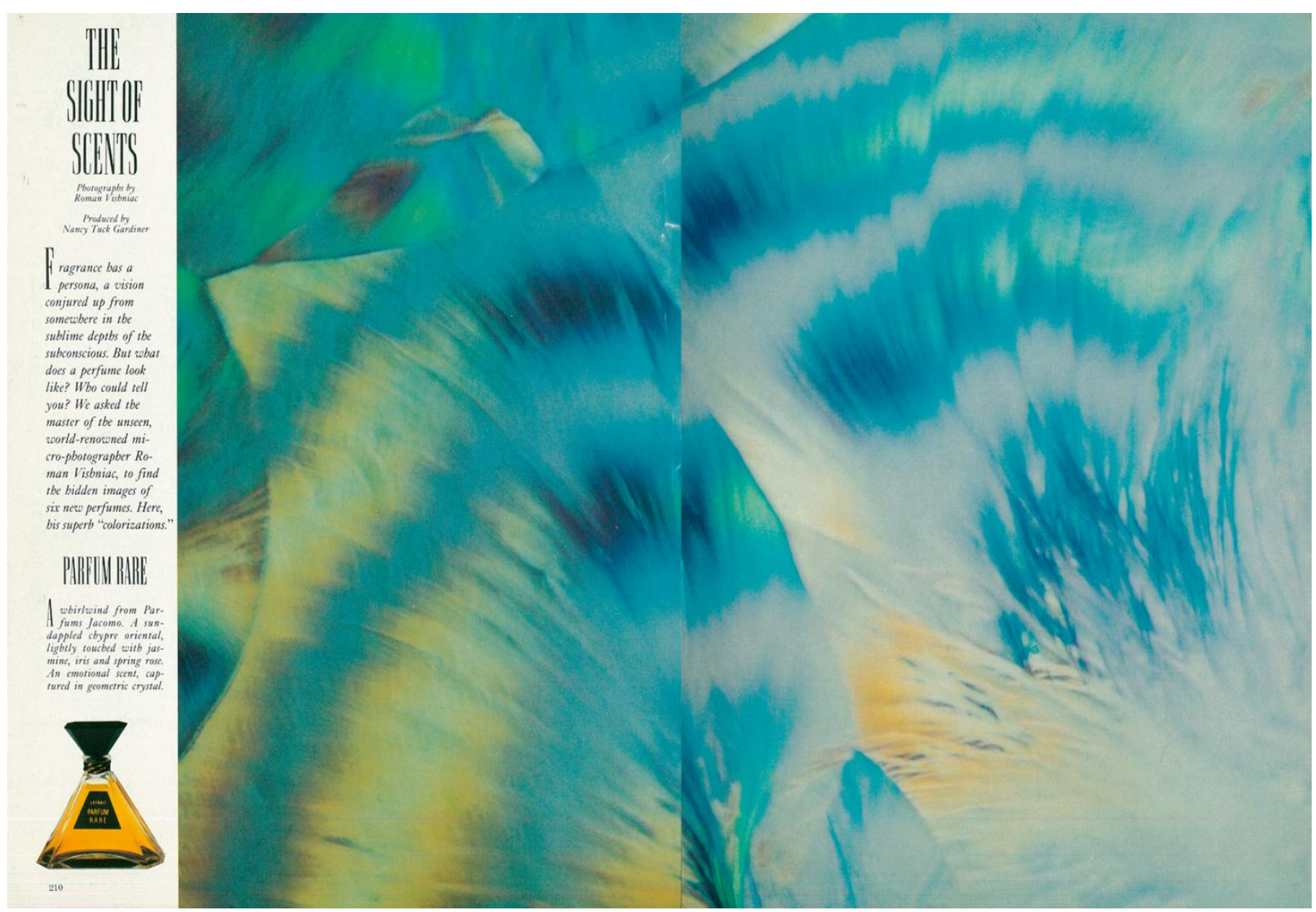

Figure 15. The Sight of Scents. Two double page spreads of polarized light photomicrographs of crystal precipitates from perfume samples. Editorial project produced by Vishniac while in his mid-eighties. Town and Country Magazine, Vol. 139, No. 9, November 1985. Reprinted by permission of Hearst.

a short memory. The nature of scientific pursuit is to be driven by forward-looking progress for the new or "better" result. That which is past is not necessarily of great interest. British physiologist Sir Peter Medawar (1960 Nobel) summing-up this viewpoint stated, "... the history of science bores most scientists stiff...”. (Medawar 1968) Similarly, Carmody describes that science idealizes process and obliterates the excitement and wonder of discovery. (Carmody 2001) In this vein, the accepted and promulgated view that science is a linear, deductive and reductive process would be the antithesis of Vishniac's previously described Romantic view of nature; perhaps making Vishniac's fit with conventional science a difficult one. Given these considerations it is likely that few older and "past", holistic images and programs would remain of interest to the sciences and scientists.

Turning attention to the world of art, the question arises not only in regard to Vishniac but more broadly: How and why does and any creative effort or endeavor become, or become recognized as "art"? More specifically, how and why does some intentdriven or applied work become "art" - or at very least an "art world interest" - while some does not? Why is scientific and technical imagery ghettoized? This question often arises in relation to any work not created in the spirit of ars gratia artis. Clearly Vishniac's commissioned, humanistic, documentary photography - created with the intent to support charitable fund-raising - has been admitted to the canon of $20^{\text {th }}$ century art relatively briskly without the patina lent by a lengthy period of passing time. This, in a manner similar to the contemporaneous and congenerous documentary photography work by Dorothea Lange, Arthur Rothstein, Ben Shahn and others commissioned by the Works Progress and the Farm Security Administrations in the US. Analogously, relatively current work from the editorial and advertising worlds by photographers such as Irving Penn and Richard Avedon is actively exhibited on the walls of prominent museums as this is written.

Hewing more closely to scientific images, Anna Atkins' cyanotypes of marine flora and Eadweard Muybridge's timemotion studies are oft- and well-recognized for their beauty as well as scientific validity. Leo Tolstoy, the Russian writer and critic stated, "... it is difficult to say what is meant by art, and especially what is good, useful art ..."; validating the premise that art may indeed have a use or purpose. (Tolstoy 1995 [1897]) Demonstrably then, neither the intent, nor the age, nor the subject of images are disqualifying factors in consideration of an image's potential recognition as a work of art.

Perhaps as posited by Peres \& Malin “... there is still an ambiguity associated with this type of photography. Just as the intent 

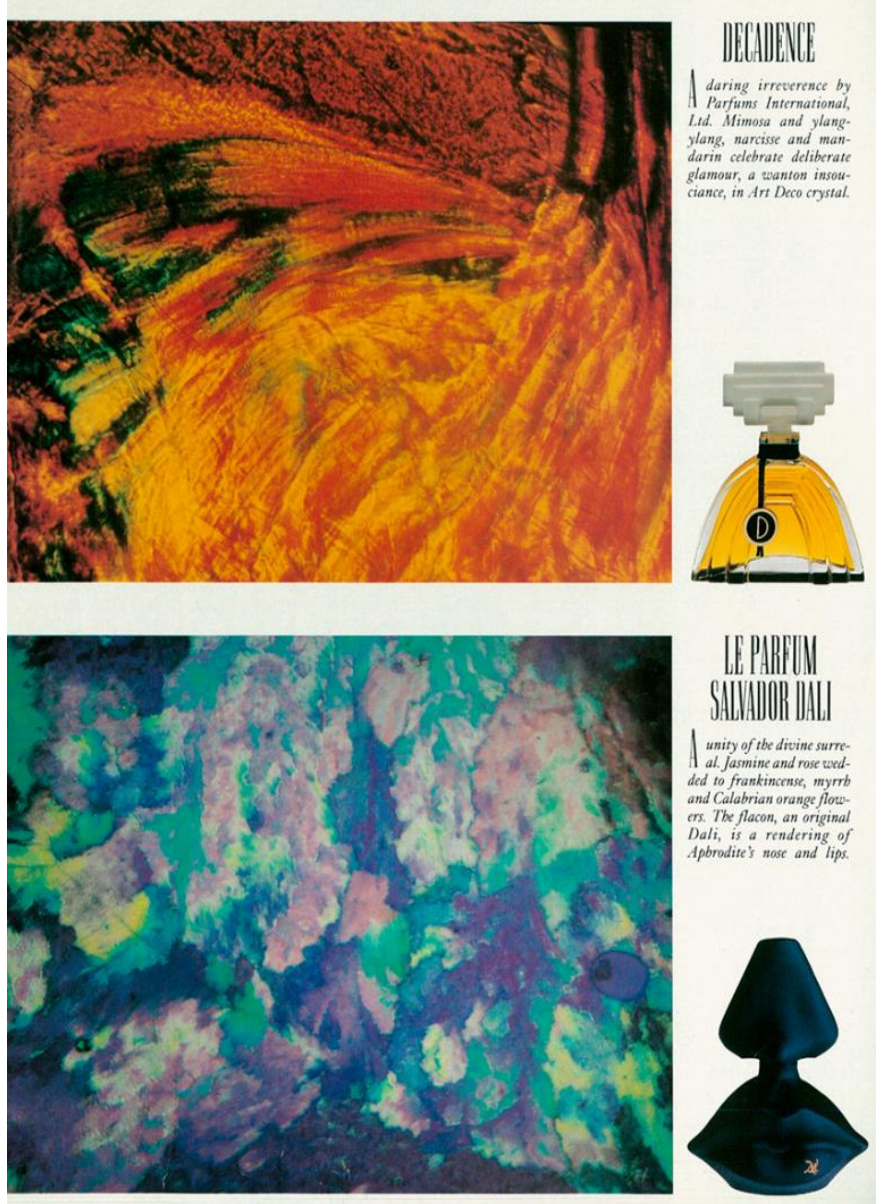

212
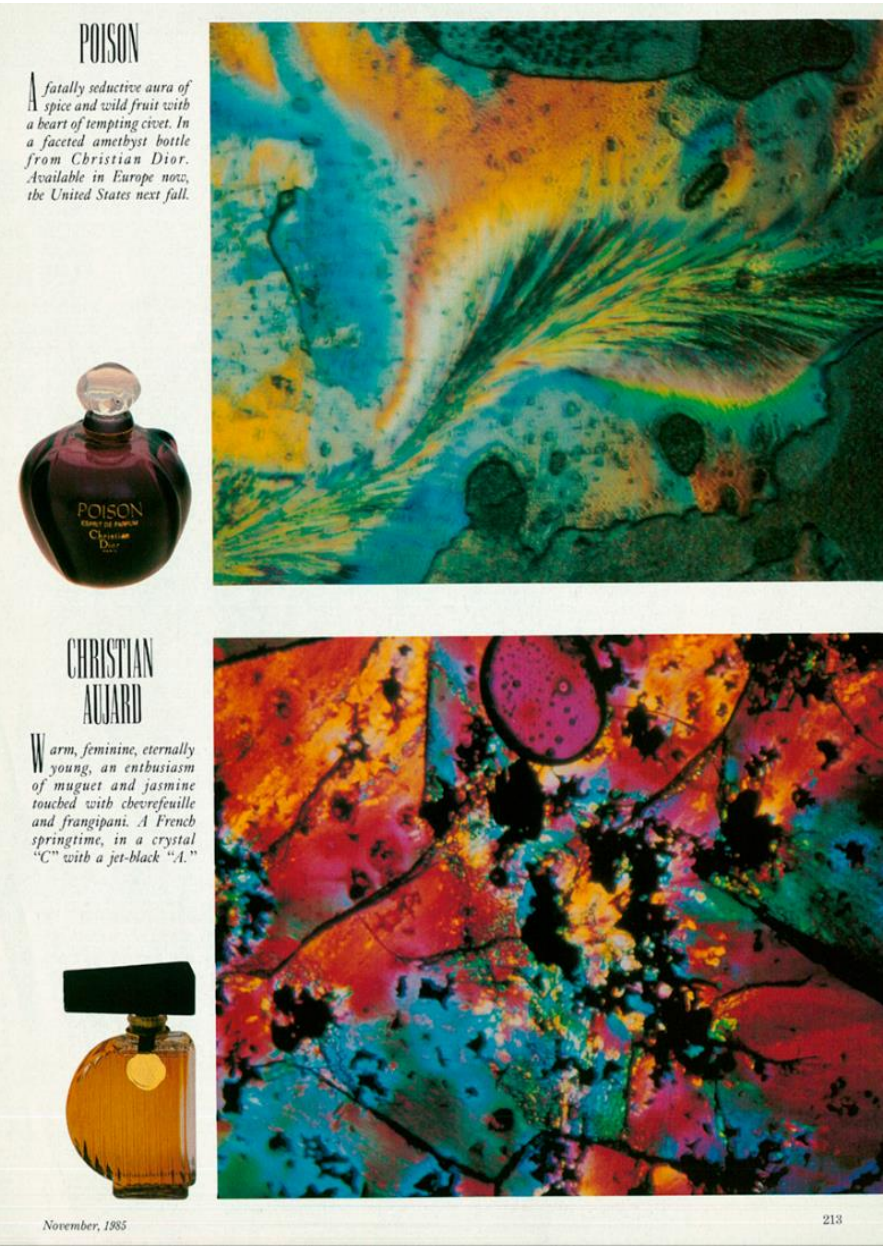

of the photographer decides what category of image will be made, so it is the mindset of the beholder that decides if it is art or science.". (Peres \& Malin 2007) In a similar tone, in 1952 Vishniac was quoted as saying, " "The purpose of photography is the transmission of a visualized sector of life through the medium of the camera into a mental process that starts with the photographer's thinking about the subject he photographs and is continued in the mind of the spectator.' ". (Deschin 1952) If so; what was Vishniac's intent and process? Did Vishniac view his images as art and himself as an artist?

Noted above are Vishniac's statements relating to artistry in the photographs contained in the introduction to his 1971 monograph. (Vishniac 1971) This was certainly not his only connection to the world of art or to artistic consideration of his biological photography. Selections of Vishniac's biological photography (along with the work of many other scientific photographers) were included in exhibitions of photography at the Museum of Modern Art (MoMA) curated by Edward Steichen in 1951 (MoMA 1951) as well as by his successor John Szarkowski in 1964 (MoMA 1964), and are held in the museum's permanent collection. A MoMA press release announcing a 14 March 1963 lecture panel Three Photographers in Color in which Vishniac participated, stated: "Vishniac's present interest is in the integration of art and science.". (MoMA 1963) From 1959 continuing through at least 1967 , in the midst of his most prolific period in biological photography, Vishniac served as an advisor on photography to the Cleveland Museum of Art (CMA) and lectured at the museum in 1960, 1962 and 1967. The museum's press release for a 1967 lecture states: "His film and slides are not only of scientific worth, but have artistic value as well.”. (CMA 1967)

In January 1971 a selection of Vishniac's scientific photographs were exhibited in NYC at the Neikrug Galleries alongside the underwater photographs of Douglas Faulkner. A. D. Coleman in his NYT review described the two men as, "... two photographers best known for their studies of hidden, natural worlds.". Discussing Vishniac's photomicrographs Coleman wrote: "Even if one cannot fully appreciate their scientific significance, their aesthetic impact is undeniable. One, called, "Festival of Fire" has an explosive intensity which makes it seem monumental. Another is so reminiscent of Van Gogh's tonal palette and linear dynamic that one at first glance could mistake it for a painting - a statement which is only rarely, as in this case, complimentary." (Coleman 1971) Vishniac's nonscientific, metaphorical titling of an image, and display of his scientific images in the initial photography show of a gallery whose founder (Marjorie Neikrug) stated: " " The time has come to introduce the public to the fine artistic quality of color photography ..., ", (ibid.) unquestionably identify and support Vishniac's view of his images as art. Note also Coleman's statement regarding the type of imagery for which Vishniac was "best known". 

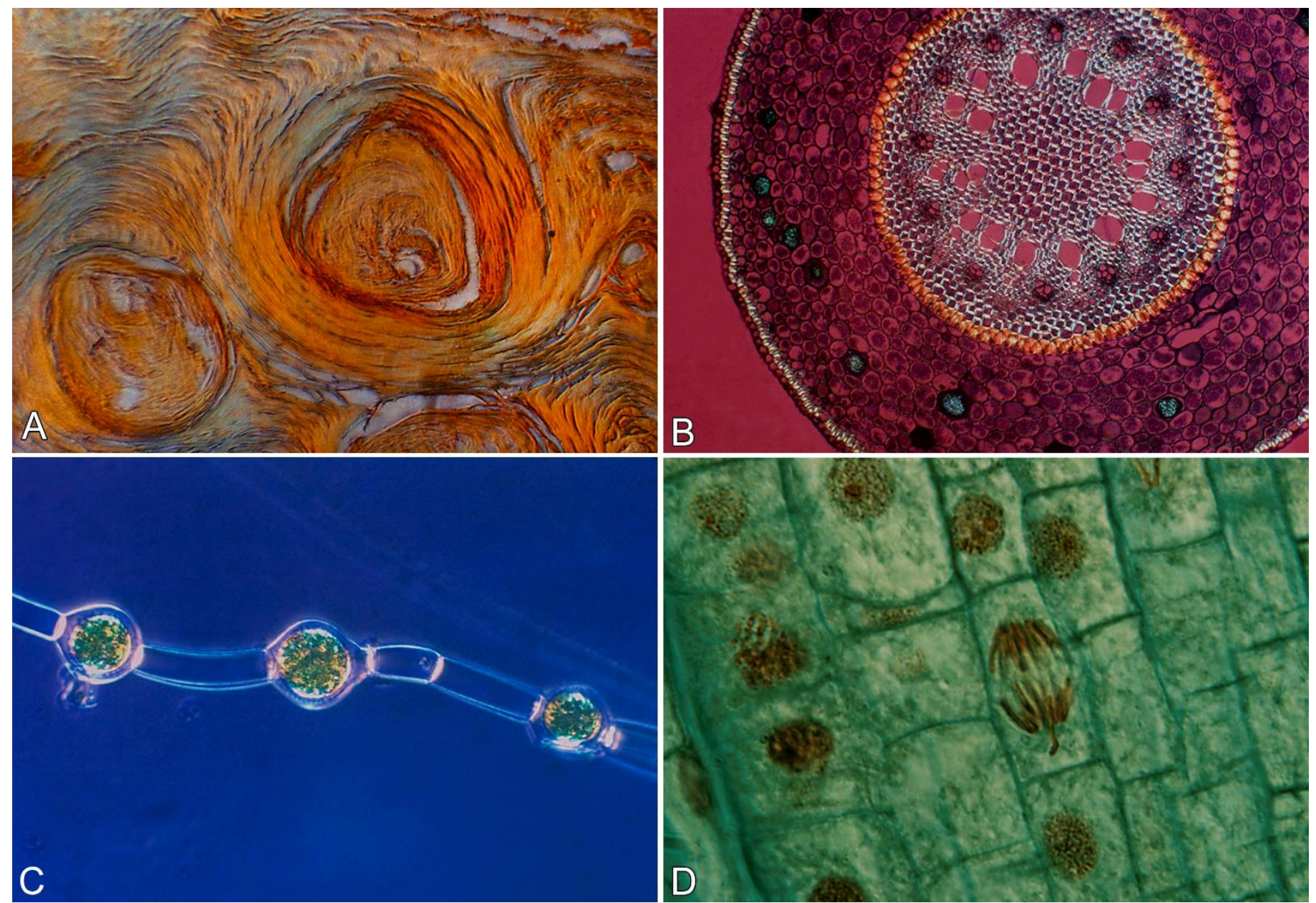

Figure 16 A-D. Classic examples of Vishniac's photomicrography (all magnifications as noted on originals): A. Fresh, horizontal, thick-section of skin from Roman Vishniac's thumb," colorization", x40, 1950s-1962. Mara Vishniac Kohn recalls her father slicing this specimen from his thumb. (Radzyner 2106B) B. Central core plant tissue, polarized light and Rheinberg illumination, x10, 1950s-1962. C. Oedogonium (Green Algae), interference contrast, x100, 1950s1970s. D. Plant mitosis, transillumination, x100, early 1950s-1970s @ Mara Vishniac Kohn, Courtesy International Center of Photography.

The 1971 ICP retrospective exhibition that contained both Vishniac's scientific and documentary photographs travelled extensively after completing its run in NYC and was exhibited at art museums as prominent as the Corcoran Gallery of Art in Washington, DC. The NYT's reviewer of the NYC exhibition wrote: "This show is not intended to be an aid to understanding the things depicted, or even a demonstration of color microphotography's (sic) ability to depict them. It is, rather, an attempt to extract an esthetic experience out of what at first thought seems most unpromising material ...". (Thornton 1971)

Peres \& Malin further their discussion on the question of the potential of art in scientific photography writing, “ $\ldots$ in these ways, through inspiration, insight and expression that images of science may also occasionally, by chance or design, be works of art. It is a rather small departure from this to deliberately make scientific images that are intended to be aesthetically pleasing but that almost incidentally include scientific subjects and use scientific equipment, ideas or techniques.". (Peres \& Malin 2007) We believe that Vishniac was keenly aware of the aesthetics of many of his images. Dating back at least as far as his "Colorization" technique he intended to demonstrate that both increased scientific insight as well as viewer attention could be generated by creating more alluring images.

Addressing the scientific component of the 2016 display of the Roman Vishniac Rediscovered exhibition's appearance in San Francisco a reviewer in SciArt Magazine wrote, “... in viewing his works en masse we see a man bent on using photography not simply as a technology of documentation, but as a tool to inspire awe and consideration. He could have framed and lit his microscopic subjects in conventional ways but instead he made choices that appealed to our aesthetic sensibilities, thereby rendering his work beyond simple representation. ... Scientific photography - particularly of microscopic subjects - is rarely held with the same artistic reverence as social documentary photography. This may be because the subjects seem foreign to most viewers, and therefore lack common visual references. ... If the aim of art is to provide insight or inspiration that is unattainable through other means, then microscopic photography (sic) is worthy of consideration as an artistic medium.". (Ferguson 2016)

Thus, much as we acknowledged as we began this discussion, 
we return to the paradox of the neglect of Vishniac's biological photography without providing a definitive answer or reason for this occurrence. As artists who photograph, illustrate and communicate aspects of science, we recognize and appreciate Berenice Abbott's sentiment in discussing her photographs of scientific subjects, which included both biology and physics, and which were contemporaneous with Vishniac's: "Surely, scientific truth and natural phenomena are as good subjects for art as are man and his emotions, in their infinite variety.". (Abbott 1959)

\section{References}

Abbott, Berenice 1959 The Image of Science, Art in America 47:4 (Winter 1959) p.76-79

AMNH 1950 Vishniac, Press Release, 8 March 1950, Central Archive 1268, American Museum of Natural History Library

AMNH 1951 Vishniac, Press Release, 5 April 1951, Central Archive 1268, American Museum of Natural History Library

ASMP 1955 American Society of Media Photographers, Member File

Barber, Alden G. 19731972 Annual Report to Congress - Boy Scouts of America, House Document 93-67) pg.31

Barker, Norman 2015A The Curious Microscopist in Roman Vishniac Rediscovered, Benton, Maya (ed.) Delmonico Books - Prestel, New York, NY, 2015 pgs. 296-300

Barker, Norman 2015B "The Curious Microscopist" presented at Roman Vishniac Rediscovered: A Symposium, New York, NY 25 October 2015

Belkin, Samuel 1961 Letter, Belkin to Vishniac, 1 September 1961, YU Archive, Belkin File, Folder: Dr. Vishniac - Living Biology Films

Benton, Maya 2015A Benton, Maya (ed.) Chronology and Bibliography Roman Vishniac Rediscovered, Delmonico Books - Prestel, New York, NY, 2015 pgs. 358-373

Benton, Maya 2015B Vishniac on Assignment in Benton, Maya (ed.) Roman Vishniac Rediscovered, Delmonico Books Prestel, New York, NY, 2015 pgs. 108-120

Benton, Maya 2015C (ed.) Roman Vishniac Rediscovered, Delmonico Books - Prestel, New York, NY, 2015

Broadcasting 1969 NBC Draws 106 Emmy Nominations, Vol. 76 No. 19, 12 May 1969, pg. 64

Capa, Cornell 1972 (ed.) Concerned Photographer 2, Grossman Publishers Division of Viking Press, New York, NY 1972

Capa, Cornell 1974 (ed.) Roman Vishniac - ICP Library of
Photographers Vol. 6, Grossman Publishers Division of Viking Press, New York, NY 1974

Carmody, John 2001 Celebrating Science, Nature 412:383, 26 July 2001

CMA 1967 Public Relations Office Press Release, Cleveland Museum of Art, 29 September 1967, Accessed 22 October 2017 https://archive.org/details/cmapr0887

Coleman, A. D. 1971 A World Most Never See, NYT Vol 120 No. 41,280, Section 2 (Arts \& Leisure) pg. 20, 31 January 1971

Conal, Barney 1962 Memorandum, Conal to S. Belkin, 17 December 1962, YU Archive, Belkin File, Folder: Dr. Vishniac - Living Biology Films

Deschin, Jacob 1952 Nature as it Is NYT Vol 1101 No. 34,343, Section 2 pg. 14x, 3 February 1952

Disney 1958 Secrets of Life, Directed by James Algar. Los Angeles, CA: Walt Disney Productions 1958

Edelson, Michael 1971 The Concerns of Roman Vishniac, Infinity, 1971, Vol. 20 No. 10, pgs. 4-18, October 1971

Edgerton, Harold 1957-1961 Correspondence, Edgerton to/from Vishniac, Massachusetts Institute of Technology, Institute Archives and Special Collections, Papers of Harold E. Edgerton Box 46, Folder 14

Edgerton, Harold 1959 Letter, Edgerton to Vishniac, 28 April 1959, RVA-ICP Drawer 3, Folder 5-12

Eskildsen, Ute 2015 The Strolling Observer in Roman Vishniac Rediscovered, Benton, Maya (ed.) Delmonico Books - Prestel, New York, NY, 2015 pgs. 42-50

ETS 1958A The Worlds of Dr. Vishniac, Directed by Arthur Zegart, Princeton, NJ Educational Testing Service 1958

ETS 1958B The Worlds of Dr. Vishniac Discussion and Study Guide, YU Archive, PR - People, Box 126, Folder RV

Ferguson, Joe 2016 Roman Vishniac Rediscovered at The Contemporary Jewish Museum in San Francisco, Review, SciArt Magazine 11 March 2016, Accessed 10 January 2018 https://www.sciartmagazine.com/blog/review-roman-vishniacrediscovered-at-the-contemporary-jewish-museum-in-sanfrancisco

FMNH 1950 Chicago Natural History Museum Bulletin Vol. 21 No. 10, October 1950 https://biodiversitylibrary.org/page/4375271

Fraser, James H., Vishniac Kohn, Mara and Pomerance, Aubrey (eds.) 2005 Roman Vishniacs Berlin, Jüdisches Museum Berlin - Nicolai Verlag, Berlin, Germany, 2005 
Gulick, William D. 1962 Letter, Gulick (Roche Laboratories, Dir. Of Advertising) to Vishniac, 24 October 1962, RVA-ICP Drawer 3, Folder 5-2

Hauschka, Theodore S. 1956 Letter, Hauschka (Director, Experimental Biology) to Vishniac, 9 November 1956, RVAICP Drawer 3, Folder 15-6

Hechinger, Fred M. 1960 Biologist to Film Unseen World, NYT Vol 109 No. 37,466, pg. 2, 22 August 1960

Hersey, John 1984 Letter, Hersey (AAA\&L Chancellor) to Vishniac, 7 March 1984, AA\&L Member Files (including nomination form and support letters)

Holt, Clare 1940 Letter, Holt to Emma Woytinski, 18 September 1940, RVA-ICP Drawer 1, Folder 4-5

Johnson, Ken 2013 His Vanished (or Manipulated?) World, NYT Vol. 162 Issue 56,097, pg. C28, 5 April 2013

Kelly, Harry, C. 1960 Letter, Kelly (NSF) to S. Belkin, 8 June 1960, YU Archive, PR People, Box 126, Folder: Vishniac, Roman 1960-1974

Kinkead, Eugene 1955A The Tiny Landscape I, The New Yorker Vol. 31 No. 20, pgs. 28-49, 2 July 1955

Kinkead, Eugene 1955B The Tiny Landscape II, The New Yorker Vol. 31 No. 21, pgs. 31-52, 9 July 1952

Kinkead, Eugene 1955C Spider, Egg, and Microcosm: Three Men and Three Worlds of Science, Alfred A. Knopf, New York, NY, 1955

Lerner, Irwin 1964 Letter, Lerner (Roche Laboratories, Dir. Of Advertising) to Vishniac, 22 October 1964, RVA-ICP Drawer 3, Folder 4-18

Library of Congress 1954 Catalog of Copyright Entries: Third Series: 1953 January-June pg. 340 (LCCN fi53001141, OCLC 546118)

Library of Congress 1969 Catalog of Copyright Entries: Third Series: 1969 January-June pg. 4 (LCCN MP18944)

LIFE 1945 Insect Enemies, Vol. 19 No. 9, 27 August 1945, pgs. 59-64

https://books.google.com/books?id=e0gEAAAAMBAJ\&pg=P A59\&dq=\%22Insect+Enemies\%22\&hl=en\&sa=X\&ved=0ahU KEwi8kc6frYTbAhUCSN8KHYSaBeQQ6AEIKTAA\#v=one page \&q=\%22Insect $\% 20$ Enemies $\% 22 \& \mathrm{f}=$ false

LIFE 1951 New Way to See Living Things, Vol. 31 No. 25, 17 December 1951, pgs.124-128

https://books.google.com/books?id=Y1QEAAAAMBAJ\&q= $\% 22$ new + way+to+see+living+things+process + shows $\% 22 \# \mathrm{v}=$ snippet\&q=\%22new $\% 20$ way $\% 20$ to $\% 20$ see $\% 20$ living $\% 20$ thin gs $\% 20$ process $\% 20$ shows $\% 22 \& \mathrm{f}=$ false
LIFE 1952 Why Insects Change Form, Vol. 32 No. 6, 11 February 1952, pgs. 79-87

https://books.google.com/books?id=i1QEAAAAMBAJ\&pg=P A79\&dq=\%22WHY+INSECTS+CHANGE+FORM\%22\&hl= en\&sa=X\&ved=0ahUKEwiN-3HrITbAhVQGt8KHREQDoA Q6AEIKTAA\#v=onepage $\& q=\% 22 \mathrm{WHY} \% 20$ INSECTS $\% 20 \mathrm{C}$ HANGE\%20FORM\%22\&f=false

LIFE 1953 Creatures of the Sea, Vol. 35 No. 2, 30 November 1953, pgs. $79-108$ (q.v.: pg. 101) https://books.google.com/books?id=2UgEAAAAMBAJ\&pg= $\underline{\text { PA79\&dq }=\text { Creatures }+ \text { of }+ \text { the }+ \text { Sea\&hl=en \&sa }=X \& v e d=0 a h U}$ KEwjcgf3CrYTbAhXlkOAKHWHtAm8Q6AEIKTAA\#v=one page \&q=Creatures $\% 20$ of $\% 20$ the $\% 20$ Sea $\& f=$ false

LIFE 1955 The World of the Insects, Vol. 39 No. 6, 8 August 1955, pgs. 43-55 (q.v.: pgs. 48-49)

https://books.google.com/books?id=ylYEAAAAMBAJ\&print

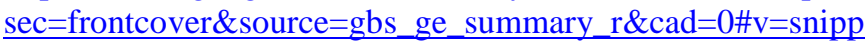
et\&q=world $\% 20$ insects $\% 20750 \% 2 \mathrm{C} 000 \& \mathrm{f}=$ false

Luck, Martin 2014 Hormones: A Very Short Introduction, Oxford University Press, New York, NY 2014

Lutz, Benton \& Fulton, George 1954 The Use of the Hamster Cheek Pouch for the Study of Vascular Changes at the Microscopic Level, The Anatomical Record 120:1, 293-307 1954

Ma, Yue \& Tam, Herb 2015 Vishniac's Chinatown in Roman Vishniac Rediscovered, Benton, Maya (ed.) Delmonico Books - Prestel, New York, NY, 2015 pgs. 288-291

Malkames, Karl 1993 Letter, Malkames to Mara Vishniac Kohn, 15 June 1993, RVA-ICP Drawer 2, Folder 21-6

Medawar, Peter B. 1968 Lucky Jim, Review, The Double Helix by James Watson. The New York Review of Books 10:6, 28 March 1968, pgs. 3-5.

Mitgang, Herbert Testament to a Lost People, NYT Vol. 138 Issue 45,819 Magazine pgs. 40-41, 53 October 2, 1983

MoMA 1951 Museum of Modern Art New York, Exhibition Records, 476.1, Accessed 10 January 2018 https://www.moma.org/documents/moma_master-checklist 3 $\underline{25775 . p d f}$

MoMA 1963 Museum of Modern Art New York, Press Release, 4 March 1963, Accessed 10 January 2018 https://www.moma.org/momaorg/shared/pdfs/docs/press_arch ives/3119/releases/MOMA_1963_0031_30.pdf?2010

MoMA 1964 Museum of Modern Art New York, Exhibition Records, 736.1, Accessed 10 January 2018 https://www.moma.org/documents/moma_master-checklist_3 26331.pdf 
Newhouse, Alana 2010 A Closer Reading of Roman Vishniac, NYT Vol. 159 Issue 55,000 Magazine, 4 April 2010 pg. MM36 - MM43

NSF 1961 Letter, NSF to Vishniac, 25 November 1961, RVAICP Drawer 3, Folder 1-5

NYT 1941 New York Times Vol. 90 No. 30,543, pg. 17, 8 August 1941

Peres, Michael R. and Malin, David 2007 Science As Art in Peres, Michael (ed.) The Focal Encyclopedia of Photography, Digital Imaging, Theory and Applications, Fourth Edition, Focal Press, New York, NY, 2007, pgs. 492-495,

Radzyner, Howard. J. 1993 "Dr. Roman Vishniac: An Appreciation." Proceedings 63rd Meeting of the Biological Photographic Association; Stamford, CT June 1993 pg. 4

Radzyner, Howard J. 2016A Personal communication from Eugene McDermott to Howard J. Radzyner 5 May 2016

Radzyner, Howard J. 2016B Personal communication from Mara Vishniac Kohn to Howard J. Radzyner 18 October 2016

RVA- ICP c. 1990 Curatorial inventory of prints from 1971 exhibition The Concerns of Roman Vishniac: Man, Nature and Science conducted by ICP staff, RVA-ICP Drawer 1, Folder 13-1

Sabin, Francene 1978 The Photomicrographic World of Roman Vishniac OMNI 1:1 pgs. 72 - 81 October 1978

Sawyer, Philip N. 1990 More About Heroes, Editorial, Journal of Investigative Surgery, 3:3, 191-192, 1990

Scherer, Paul A, 1962 Letter, Scherer (NSF) to S. Belkin, YU Archive, PR People, Box 126, Folder: Vishniac, Roman 19601974

Shepard, Richard F. Roman Vishniac, 92 a Biologist And Photographer of Jews Dies NYT Vol. 139 No. 48,124, pg. D23, 23 January 1990

SMPTE 1980 SMPTE Journal 89:38 January 1980

Soyfer, Valery N. 2001 The Consequences of Political Dictatorship for Russian Science, Nature Reviews Genetics 2, 723-729 (September 2001)

Speidel, Carl C. 1946 The Papers of Carl Caskey Speidel, Historical Collections, Claude Moore Health Sciences Library University of Virginia, Charlottesville, VA: Box-Folder 03:3135

The Shell Companies 1963 BREAKTHROUGH, Advertisement, LIFE, Vol. 55 No. 11, 13 September 1963, pgs. 68-69. https://books.google.com/books?id=N1IEAAAAMBAJ\&q=th $\underline{\mathrm{e}+\text { Shell}+ \text { Companies\#v }=\text { snippet } \& \mathrm{q}=\text { Breakthrough } \% 20 \text { found } \%}$ 20hidden\%20world\%20frightening\%20enemies\%20unfailing \&f=false

Thornton, Gene 1971 The Two Roman Vishniacs, NYT Vol 121 Issue 41,553, pg. D25, October 31, 1971

TIME 1976 The Bugs are Coming, Vol. 108 No. 2, 12 July 1976, Cover

Tolstoy, Leo 1995 [1897] What is Art? Translated by Richard Pevear and Larisa Volokhonsky, London, Penguin Books, 1995, pg. 9

Town \& Country 1985 The Sight of Scents, Vol. 139 No. 9, November 1985, pgs. 210-215

Vishniac, Roman 1941 Letter, Vishniac to NY Zoological Society, 18 October 1941, RVA-ICP Drawer 1, Folder 8-11

Vishniac, Roman 1943 Manuscript fellowship application, John Simon Guggenheim Memorial Foundation Archives, File: Vishniac, Roman

Vishniac, Roman 1950 Color Photomicrography Exakta Magazine, Winter 1950-51, Vol. 1 No. 3, pgs. 16-17

Vishniac, Roman 1951 “A New Application of Polarization Optics to Cytological Studies of Living Tissues", Proceedings American Society of Zoologists $48^{\text {th }}$ Annual Meeting in The Anatomical Record 111:3, 4691951

Vishniac, Roman 1956 The Living Earth - National Audubon Society Nature Program, Nelson Doubleday Incorporated, Garden City, NY 1956

Vishniac, Roman 1957A Mushrooms - National Audubon Society Nature Program, Nelson Doubleday Incorporated, Garden City, NY 1957

Vishniac, Roman 1957B NIH Application for Research Grant, YU Archive, Belkin File, Folder: Dr. Vishniac - Living Biology Films, 28 June 1957

Vishniac, Roman 1959 Manuscript, "A Proposal to the National Science Foundation for a Living Biology Film Series", YU Archive Box 1993.004, Folder: Dr. Roman Vishniac 1959-1961

Vishniac, Roman 1965 Effects of Small Electrical Currents and Dying Tissue on Blood Flow in the Rat Mesenteric Blood Vessels, in Biophysical Mechanisms in Vascular Homeostasis and Intravascular Thrombosis, Sawyer, Philip N. (ed.), Appleton-Century-Crofts Division, Meredith Publishing Company, New York, NY 1965, pgs. 138 - 146

Vishniac, Roman 1966A Mushrooms - National Audubon Society Nature Program, Nelson Doubleday Incorporated, Garden City, NY 1966

Vishniac, Roman 1966B The Microworld Boy's Life 56:11, November 1966, pgs. 28-31 
Vishniac, Roman 1967A Mystery Under the Microscope Boy's Life 57:4, April 1967, pgs. 28-29

Vishniac, Roman 1967B Through the Magic Eye Boy's Life 57:10, October 1967, pgs. 28-29

Vishniac, Roman 1969 Keeping a Microworld Boy’s Life 59:1, January 1969, pgs. 40-41

Vishniac, Roman 1971 Building Blocks of Life: Proteins, Vitamins and Hormones Seen Through the Microscope, Charles Scribner's Sons, New York, NY 1971

Vishniac, Roman 1983 A Vanished World, Farrar Straus and Giroux, New York, NY 1983

Vishniac, Wolf 1961 Letter, W. Vishniac to R. Vishniac, 25 November 1961, ICP-RVA Drawer 3, Folder 1-8

Vishniac Kohn, Mara \& Hartmann Flacks, Miriam (eds.) 1999 Children of a Vanished World: Photographs by Roman Vishniac, University of California Press, Oakland, CA 1999

Warner-Pathé 1956 Newsmagazine of the Screen Vol. 7, No. 4

Wiesel, Marion 1993 To Give Them Light: The Legacy of Roman Vishniac Wiesel, Marion (ed.), Simon \& Schuster, New York, NY 1993

Wilson, Frank 1940 Letter, Wilson to Vishniac, 15 March 1940, RVA-ICP Drawer 3, Folder 14-10

Wilson, John T. 1957 Letter, Wilson (NSF) to Vishniac, 16 October 1957, YU Archive Belkin File, Folder: Dr. Vishniac Living Biology Films

\section{Acknowledgements}

Mara Vishniac Kohn and the Estate of Roman Vishniac

Roman Vishniac Archive at the International Center of Photography - Maya Benton and Susan Carlson, Curators

University of South Carolina, Moving Image Research Collections, Roman Vishniac: The Subject is Nature - Heather Heckman, Curator

Yeshiva University - Deanna Schwimmer, Archivist

Professor Michael Edelson - State University of New York at Stony Brook

Dr. Ethan Vishniac - Johns Hopkins University

Society of Motion Picture and Television Engineers - Barbara Lange, Executive Director

American Society of Media Photographers - Tom Kennedy, Executive Director
American Academy of Arts \& Letters - Nancy Malloy, Archivist

New York Entomological Society - Louis Sorkin, Treasurer

National Science Foundation - Dr. Leo Slater, Historian

New York Microscopical Society - Melvin Pollinger, Secretary

Field Museum of Natural History - Gretchen Rings, Archivist

American Museum of Natural History - Mai Reitmeyer, Archivist

Massachusetts Institute of Technology Libraries - Myles Crowley, Research Associate

John Simon Guggenheim Memorial Foundation - André Bernard, Secretary

Eugene McDermott, RBP, FBCA

Thomas St.J. Merrill, FBCA

A. Clifford Pollack, RBP, FBCA

Martin L. Scott, FBCA

Jan Hinsch, FNYMS

Dr. Walter Blogoslawski - National Oceanographic \& Atmospheric Administration

Herb Tam - Museum of Chinese in America

Hearst Magazines, Inc.

Time, Inc.

Oddball Films, Inc.

Estate of Phillipe Halsman

The Malkames Collection - Rick Malkames, Curator

Estate of Dr. Philip N. Sawyer

Philip Sawyer - Invuity, Inc.

Professor Michael Peres - Rochester Institute of Technology

Dr. William Ambler - New York University

Professor Scott Curtis - Northwestern University

Howard Greenberg Gallery - Nancy Lieberman, Managing Director

Ron Kurtz 
Julia van Haaften - New York Public Library

\section{Support and Funding}

Development of this manuscript would not have been possible without the support and encouragement of the Roman Vishniac Archive at the International Center of Photography including the ongoing, dedicated presence and assistance of Susan Carlson.

Research, production and publication of this article were funded in part by grants from the: Peter Hansell Fund of the Royal Photographic Society (NJB); Endowment Fund for Education, Biological Communications Association (NJB \& HJR); and viewers like you.

\section{Authors' Biographical Sketches}

Howard J. Radzyner, BS, RBP, FBCA is Principal of Radzyner, et al., LLC in New York where he provides a variety of photographic, communications and consultancy services to clients in the worlds of medicine, science, law and art. Howard's photographs have been published in journals such as Science, Cell and the New England Journal of Medicine; have illustrated numerous papers, books, exhibits and presentations; have supported submissions for product, drug and device approval before federal agencies; and have provided evidence in civil and criminal proceedings. hradzyner@radzyner.com

Norman J. Barker, MA, MS, RBP, FBCA, FRPS is Director of the Pathology Photography and Graphics Laboratory as well as Professor of Pathology and Professor of Art as Applied to Medicine at the Johns Hopkins University School of Medicine. Norman specializes in photomacrography, photomicrography and natural science photography. The author and photographer of six books; Norman's work is held in the collections of over 40 museums including the Smithsonian Institution, George Eastman House and the American Museum of Natural History. nbarkerj@jhmi.edu

\section{Licensing}

The authors have chosen to license their content under a Creative Commons Attribution, NonCommercial, NoDerivatives 4.0 International License.
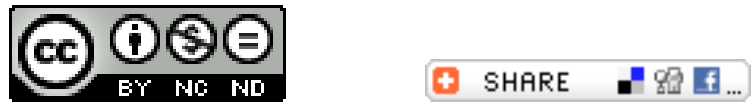

Copyright 2018, The Journal of Biocommunication; All

Rights Reserved. 